\title{
Credit Booms and Macroeconomic Dynamics: Stylized Facts and Lessons for Low-Income Countries
}




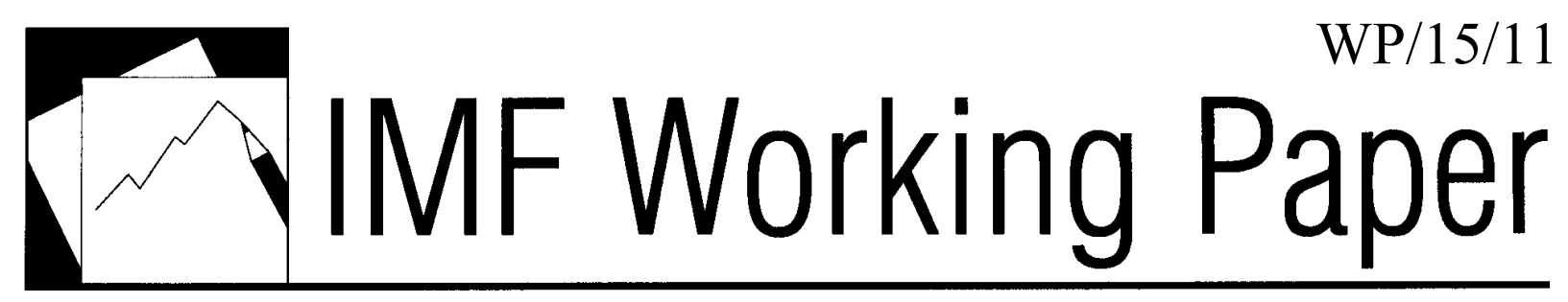

\section{Credit Booms and Macroeconomic Dynamics: Stylized Facts and Lessons for Low-Income Countries}

Marco Arena, Serpil Bouza, Era Dabla-Norris, Kerstin Gerling, and Lamin Njie 
IMF Working Paper

\title{
Credit Booms and Macroeconomic Dynamics: Stylized Facts and Lessons for Low-Income Countries
}

\author{
Prepared by Marco Arena, Serpil Bouza, Era Dabla-Norris, Kerstin Gerling and Lamin \\ Njie $^{1}$
}

Authorized for distribution by David Marston

January 2015

This Working Paper should not be reported as representing the views of the IMF. The views expressed in this Working Paper are those of the author(s) and do not necessarily represent those of the IMF or IMF policy. Working Papers describe research in progress by the author(s) and are published to elicit comments and to further debate.

\begin{abstract}
Using a comprehensive database on bank credit, covering 135 developing countries over the period 1960-2011, we identify, document, and compare the macro-economic dynamics of credit booms across low- and middle-income countries. The results suggest that while the duration and magnitude of credit booms is similar across country groups, macro-economic dynamics differ somewhat in low-income countries. We further find that surges in capital inflows are associated with credit booms. Moreover, credit booms associated with banking crises exhibit distinct macroeconomic dynamics, while also reflecting a potentially large deviation of credit from country fundamentals. These results suggest that low-income countries should remain mindful of the inter-linkages between financial liberalization, increased cross-border banking activities, and rapid credit growth.
\end{abstract}

JEL Classification Numbers: E32, E44, E51, G21.

Keywords: Credit booms, macroeocnomic dynamics, low-income countries, emerging market economies.

Author's E-Mail Address: marena@,imf.org, sbouza@,imf.org, edablanorris@imf.org, kgerling@,imf.org, and lnjie@imf.org.

\footnotetext{
${ }^{1}$ We would like to thank Chris Lane and Olaf Unteroberdoerster for their useful comments and suggestions. Also, we would like to thank Andrea Presbitero and Bin Grace Li for their very useful peer review comments. The views expressed herein are those of the authors and should not be attributed to the IMF, its Executive Board, or its management.
} 


\section{Contents}

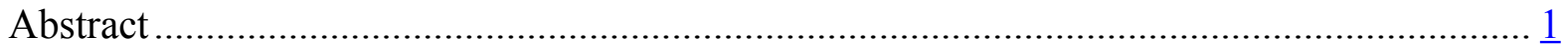

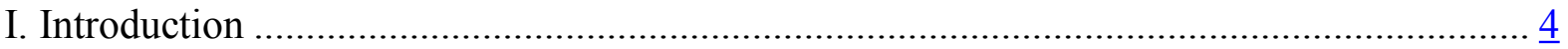

II. Credit Booms: Literature Review ……………….....................................................

III. Credit Boom Episodes, Event Study, and Empirical Assessment ……………………..... $\underline{8}$

A. Identification of Credit Boom Episodes: Stylized Facts ................................................. $\underline{8}$

B. Behavior of Macroeconomic Variables around Credit Booms ………………………. 10

C. Potential Drivers of Credit Booms ..................................................................... 13

D. Empirical Analysis of the Incidence of Credit Boom ................................................ 15

IV. Credit Booms, Banking Crisis, and Financial Deepening .............................................. 17

A. Credit Boom Episodes and Banking Crises ……………........................................ 17

B. Credit Booms and Financial Deepening................................................................... 19

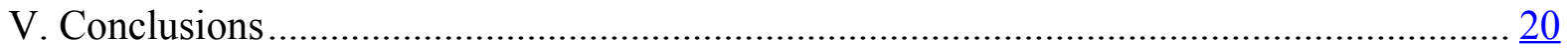

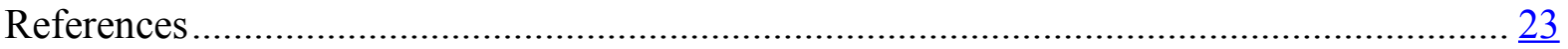

Tables

1. Number of Credit Booms Episodes: Using Real Credit per capita..................................... $\underline{25}$

2. Credit Boom Magnitudes: Income Group Summary Statistics......................................... 25

3. Duration of Credit Boom Episodes (years): Using Real Credit per capita .......................... 26

4. Credit Boom Episodes and Periods of Sustained Credit Growth ……………………....... 27

5. Correlation between Credit Booms: Real Credit per Capita and Credit-to-GDP (Mendoza and Terrones' methodology) ................................................................................... $\frac{10}{33}$

6. Capital Inflows Surges before the Peak of Credit Boom Episodes ..................................... $\frac{33}{33}$

7. Credit Booms and Exchange Rate Regimes ${ }^{1 /}$............................................................... $\frac{33}{14}$

8. Credit booms and Banking Supervision .................................................................... $\frac{14}{34}$

9. Credit Booms and Capital Inflows......................................................................... $\frac{34}{16}$

10. Marginal Effects Evaluated at Medians .................................................................... 16

11. Characteristics of Credit Booms Associated with Banking Crisis................................... 18

12. Proportion of Credit Booms Associated with Higher Financial Depth by the End of the Boom Episode................................................................................................ 19

13. Benchmarking Exercise: Financial Possibility Frontier ............................................... $\frac{19}{37}$

Figures

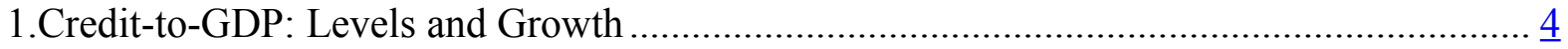

2. Credit Booms, Economic Activity and Domestic Demand ……………………………... 28

3. Credit Booms, Economic Activity and Real Exchange Rate............................................. $\frac{31}{16}$

4. Increase in the Probability of a Credit Boom............................................................ $\frac{16}{35}$

5. Credit Booms and Banking Crises ………………................................................... 35

Appendixes

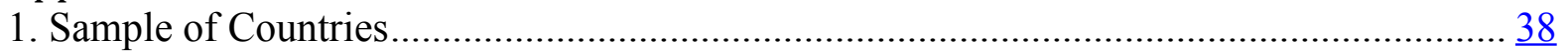

2. Description and Definition of Main Variables.............................................................. $\frac{39}{49}$

3. Boom Episodes List ................................................................................................... 
4. Robustness using the Mendoza and Terrones' methodology and application of the Tornell and Westermann's approach ........................................................................................ 41

5. Credit Booms: Significance of Event Window Coefficients ............................................... 44

6. Robustness - Credit Booms and Net Capital Inflows....................................................... $\frac{45}{46}$

7. Robustness - Credit Booms, Financial Reforms and Banking Supervision ........................ 46 


\section{INTRODUCTION}

Credit to the private sector has been growing rapidly in low-income countries (Figure 1). Fast credit growth can be reflective of improved macroeconomic prospects and deepening of relatively shallow credit markets. Indeed, in 2012, most low-income countries had credit-toGDP levels lower than in middle-income countries. But, rapid credit expansion (or credit booms) can also portend macro-financial risks, emanating from macroeconomic imbalances and banking sector distress. And while, historically, only a minority of booms has ended in debilitating financial and macroeconomic crises, the ensuing balance sheet dislocations can be very costly (Decressin and Terrones, 2011).

Figure 1.Credit-to-GDP: Levels and Growth

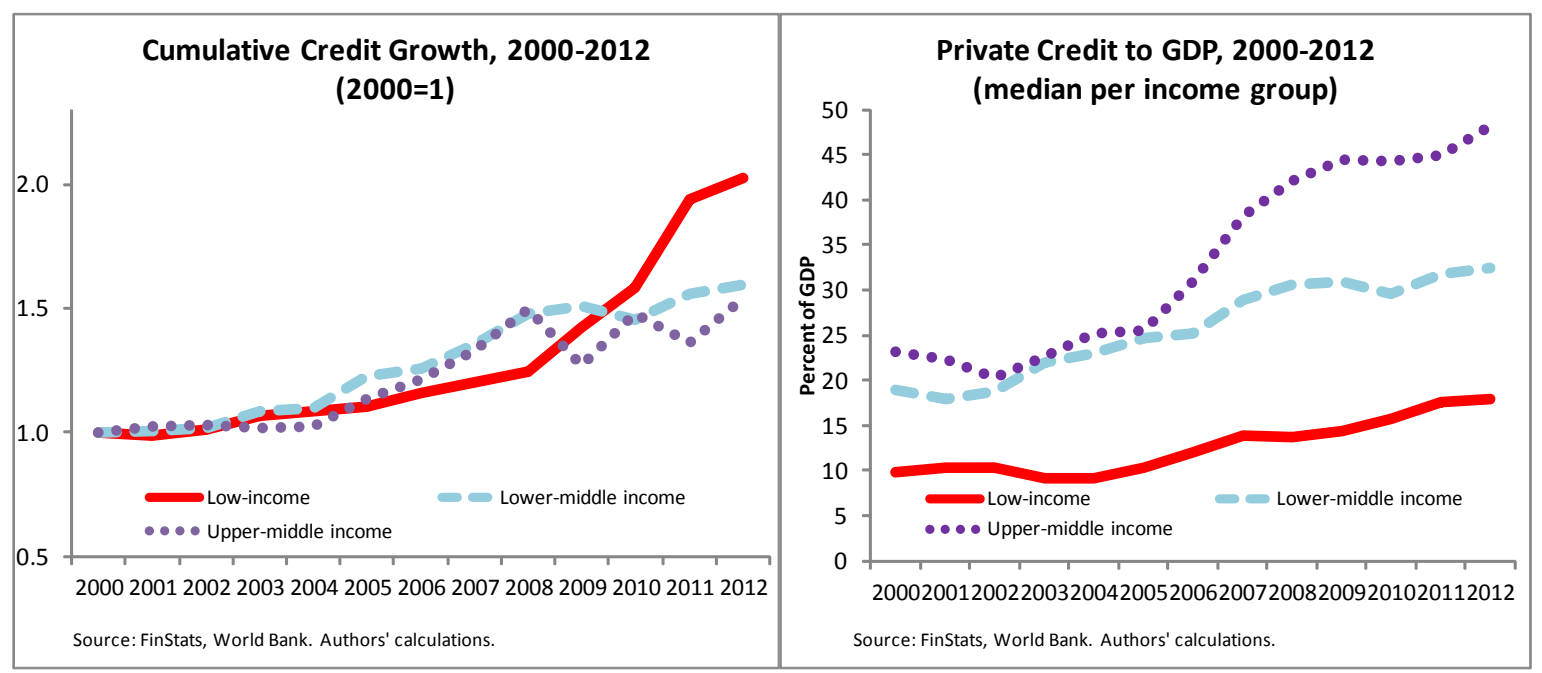

A large number of studies have developed methodologies for credit boom identification and assessed potential drivers in advanced and large emerging market economies. The evidence on the anatomy of credit booms in low- and lower-middle income countries, however, is scant. What are the characteristics of credit booms in low- and lower-middle income countries, and how do these differ from the experiences of upper-middle income countries? Is the behavior of macroeconomic aggregates around credit booms comparable to that in uppermiddle countries? Under what conditions do credit booms pose risks to financial and macroeconomic stability? When do credit booms portend beneficial financial deepening?

This paper aims to fill this gap in the literature by: (i) documenting the stylized facts of credit booms in low- and lower-middle income countries in comparison with upper-middle countries; (ii) analyzing the behavior of macroeconomic aggregates around credit boom episodes across different country groups; (iii) extracting lessons from the experiences of middle-income countries by evaluating whether credit booms that ended in banking crises exhibited particular characteristics; and (iv) examining the relationships between credit booms and financial deepening. We use a comprehensive database on bank credit, covering 135 developing countries over the period 1960-2011. Obviously, there are other sources of 
credit in the economy (bond markets, non-bank financial intermediaries, informal finance, etc.). But data availability in low-income countries renders a cross-country analysis of these alternative sources difficult, and bank credit constitutes the most important source of private credit in most emerging and developing economies. Our principal findings can be summarized as follows:

The duration and magnitude of credit booms is similar across all country groups. To identify credit booms, we apply the Mendoza-Terrones (2012) methodology by splitting real credit per capita in each country into its cyclical and trend components. Specifically, a credit boom is identified as an episode in which credit exceeds its country-specific, long-run trend by more than a given "boom" threshold. ${ }^{2}$ Our analysis suggests that the median duration of credit booms is 6 years for the full sample period, but declines to 5 years for credit booms observed over the last two decades.

Macroeconomic dynamics around credit boom episodes are more similar in lower-and upper-middle income countries than in low-income countries. Our event study analysis indicates that unlike in middle-income countries, only a subset of macroeconomic variables (e.g., economic activity, investment, non-tradable output, money balances, and external demand) exhibit a defined dynamics around credit booms in low-income countries.

Surges in capital inflows are associated with credit booms. Frequency analysis of the potential triggers of credit booms indicates that a higher proportion of credit booms in middle-income countries are preceded by an increase in capital inflows as compared to lowincome countries. This suggests that the frequency of credit booms could well increase in low-income countries as they become increasingly integrated with the global economy. Moreover, frequency analysis suggests that a significant proportion of credit booms are associated with fixed or managed exchange rates across all income groups.

Regression analysis suggests that both domestic and external factors play a role in driving credit booms. Panel probit regressions of the drivers of credit boom episodes for the period 1970 to 2011 indicate that the incidence of credit booms is positively associated with capital inflows and favorable international liquidity conditions. Further, sustained growth in economic activity and domestic private credit as well as the initial level of financial depth have a bearing on the incidence of a credit boom.

Credit booms associated with banking crises exhibit distinct characteristics compared with booms that do not end up in a banking crisis. Splitting credit booms into episodes associated with a banking crisis and non-crisis episodes, an event study analysis suggests that the dynamics of macroeconomic variables exhibit a distinct pattern around the boom episodes associated with banking crises. Moreover, macroeconomic fluctuations in this group are

\footnotetext{
${ }^{2}$ In this paper, we used the World Bank definition of low-, lower-middle, and upper-middle income countries. As a robustness test we also considered a dynamic (time-varying) income classification for countries.
} 
larger and display more abrupt declines than in other booms. In addition, using a benchmarking analysis as in Barajas et al. (2013), we find that credit growth in the majority of booms associated with banking crises was well above levels consistent with countryspecific structural factors and fundamentals.

The remainder of this paper is organized as follows. Section II provides a brief overview of the related literature. Section III identifies the credit boom events for our sample of countries, uses an event study analysis to examine the business cycle behavior of macroeconomic aggregates around the identified credit boom episodes, conducts a frequency analysis to examine the association of credit boom episodes with some of their potential drivers, and performs regression analysis to assess whether capital inflows help to predict credit booms. Section IV presents an analysis of credit booms associated with banking crises, identifying their particular characteristics and the dynamics of macroeconomic variables around these credit booms. In addition, this section presents a discussion of the association between credit booms and financial deepening in the context of a benchmarking exercise to assess whether financial depth is in line with structural and policy fundamentals.

\section{CREDit BoOMS: Literature ReVIEW}

During the last decade, a growing literature has analyzed the characteristics of credit booms and their potential consequences for the macroeconomy, financial deepening, and stability. Our paper is related to a number of strands in this literature.

A number of papers have developed different approaches for credit boom identification (Mendoza and Terrones, 2008, 2012; Gourinchas, Valdes and Landarretche, 2001; Barajas, Dell'Ariccia and Levchenko, 2009; Tornell and Westermann, 2002). Most methodologies in the literature compare a country's credit-to-GDP ratio or real credit per capita to its nonlinear trend ${ }^{3}$. But they differ in several aspects such as whether the trend and the thresholds identifying the booms are country-specific, whether information unavailable at the time of the boom is used for its identification, whether the credit and GDP series is filtered separately or directly as a ratio. In this paper, we focus primarily on the Mendoza and Terrones (2008, 2012) approach, by defining a credit boom as a deviation in real GDP per capita from a country-specific trend computed using the HP-filter (see next section for details). In contrast to their paper, we examine the anatomy of credit boom episodes for a broader spectrum of low- and lower-middle income countries and assess the robustness of our results to other methodologies identified in the literature. ${ }^{4}$

Our paper is related to the empirical literature that identifies booms in macro variables

\footnotetext{
${ }^{3}$ Some methodologies focus on absolute growth thresholds.

${ }^{4}$ Mendoza and Terrones (2012) identify 70 credit boom episodes in a cross-country analysis for 61 advanced and emerging economies spanning the period 1960-2010.
} 
using threshold methods and event-study techniques. Gourinchas, Valdes and Landarretche (2001), using a sample of 91 countries over the period 1960-96, find that credit booms are associated with a domestic investment boom, an increase in domestic interest rates, a worsening of the current account, a real appreciation, declining reserves and output growth. However, Mendoza and Terrones (2012) find that during credit booms, macroeconomic variables (such as production and absorption, asset prices, real exchange rates, capital inflows, and external deficits) display a clear cyclical pattern of economic expansion in the upswing, followed by a steep contraction in the downswing for both advanced and emerging market economies. Our paper provides a comparison of the behavior of macroeconomic aggregates across low- and middle-income countries.

Our paper is also closely related to the literature on the potential drivers of credit boom episodes. Mendoza and Terrones (2008) and Decressin and Terrones (2011) identify surges in capital inflows, total factor productivity gains, and financial reforms as potential drivers of credit booms. Dell'Ariccia et al. (2012) find that, in addition to financial reforms, capital inflow surges associated with capital account liberalizations, and periods of strong economic growth are empirically associated with credit booms. ${ }^{5}$ In addition, domestic factors matter: credit booms occur in countries with fixed exchange rate regimes, expansionary monetary and fiscal policies and low quality of banking supervision. Calderón and Kubota (2012), using a sample of 70 advanced and emerging market countries, find that surges in gross capital inflows (particularly other investment inflows) are strong empirical predictors of credit booms. We extend the analysis in these papers to cover a broader set of countries.

Our paper is also related to studies which find that credit growth can be a powerful predictor of financial crises (Borio and Lowe, 2002; Mendoza and Terrones, 2008; Schularick and Taylor, 2009; Mitra et al., 2011). ${ }^{6}$ Dell'Ariccia et al. (2012) find that booms associated with banking crises (or inferior below-trend growth) tend to be larger and last longer and that, booms that start at a higher level of financial depth are more likely to end badly. Other studies find that larger and more prolonged booms, those coinciding with higher inflation and, to a lesser extent, low economic growth are more likely to end in crises. In this paper we use event study and frequency analysis to examine the behavior of macroeconomic fluctuations in crisis versus non-crisis episodes in low- and middle-income countries.

Finally, our paper is related to a diverse literature exploring macroeconomic and institutional determinants of sound and efficient financial deepening (see, for example, Djankov et al., 2007, and Demirguc-Kunt. 2006 for a literature survey). Barajas et al.(2013) show that an

\footnotetext{
${ }^{5}$ Dell'Ariccia et al. (2012) identify credit booms for a sample of 170 countries over the period 1960-2010. However, countries with credit-to-GDP ratio of less than 10 percent are excluded from the analysis. This excludes at least 60 percent of the country-year observations for low-income countries, which are a focus of our study.

${ }^{6}$ See also Claessens et al. (2011); Borio and Drehmann (2009); Reinhart and Rogoff (2009); and Collyns and Senhadji (2002).
} 
overshooting of private credit to GDP ratio significantly beyond levels predicted by structural fundamentals is associated with credit booms and busts. In particular, they find that the probability of a crisis surpasses 10 percent for negative gaps (difference between predicted and actual values) of over 50 percent. In addition, when these large negative levels are the result of very rapid deepening above and beyond the changes in structural characteristics(say, by 30 percent or more over a ten year period) - the likelihood of instability increases even further.

\section{CREdit BoOM EPISOdes, EVENT STUdy, AND EMPIRICAL ASSESSMENT}

This section describes the definition and sources of the data used in our event study and frequency analysis and empirical assessment. We conduct a frequency analysis to examine the association of credit boom episodes with some of their potential drivers. We also outline the econometric techniques employed to estimate the relationship between the likelihood of credit booms and surges in capital inflows.

\section{A. Identification of Credit Boom Episodes: Stylized Facts}

\section{Methodology and Data}

We follow the criteria outlined in Mendoza and Terrones (2012) to identify credit booms. They define an episode as a credit boom when the amount of credit extended by the banking system to the private sector grows by more than that experienced during a typical cyclical expansion. Specifically, a country experiences a credit boom when the deviation in (log) real credit per capita from its long-run trend exceeds the standard deviation of the cyclical component by a factor of $1.65 .^{7} \mathrm{We}$ follow the authors in computing the long-run trend of real credit per capita using the Hodrick-Prescott (HP) filter. This approach allows us to both identify the main characteristics of credit booms episodes (e.g. duration and peak period of the episode) and to perform an event-study analysis around the peak of the credit boom episode.

We use data on credit from the financial sector to the private sector obtained from the IMF's International Financial Statistics (IFS) for a sample of 135 developing countries for the period 1960-2011 (see Appendix 1 for the list of countries). ${ }^{8}$ The measure of credit is the sum of claims on the private sector by deposit money banks (line 22d) plus - whenever available for the entire sample period for a given country - claims on the private sector by

\footnotetext{
${ }^{7} 1.65$ falls in the 5 percent tail of the standardized normal distribution. We also checked the sensitivity of our results to a more stringent factor of 2 (available upon request), but the qualitative results remained largely unchanged.

${ }^{8}$ See Appendix 1 for a complete list of all 135 developing countries along income groups using the 2013 World Bank's country income group classification. Out of these, 32 are low-income, 45 lower-middle-income, 43 upper-middle income countries, and 15 are high-income. Put differently, 65 are eligible for the IMF's Poverty Reduction and Growth Facility Trust (PRGT), Zimbabwe and 69 emerging markets (EM).
} 
other financial institutions (line 42d). The latter was only available for 15 countries in our sample. Discontinuities in the time series data of credit to the private sector were addressed by applying splicing techniques and gathering data from IMF staff reports. Real credit per capita is calculated as the end-of-year observations of nominal credit per capita deflated by the corresponding end-of-year consumer price index. See Appendix 2 for the complete list of variables and sources used in the paper, and Appendix 3 for the identified boom episodes.

To account for structural breaks, related to the introduction of economic and financial reforms in the late eighties and early nineties, and to mitigate countries' changes in income categories across time, we also consider a shorter sample period starting in 1994.

\section{Key features of Credit Boom Episodes}

Tables 1-3 enumerate the incidence, magnitude, and duration of credit boom episodes using the criteria outlined above for different groups of countries and time periods.

- Incidence. In total, we identify 111 credit boom episodes (see Table 1) for the full sample. Of these, 21 percent occur in low-income countries, as opposed to 38 and 29 percent in lower-middle- and upper-middle-income countries, respectively. The frequency of boom episodes has increased over time, with about 60 percent occurring in the past 20 years.

- Magnitude. At the peak of the boom, the average expansion in real credit per capita reaches around 30 percent above trend across income groups (see Table 2). It is highest in the group of low-income countries. But after normalizing by the variability of credit (the standard deviation of the cyclical component of credit in each country), consistent with Mendoza and Terrones (2012), the three income groups show a similar distribution (medians of around 2).

- Duration. Across all income groups, we find that the median and mean duration of booms is roughly 6 years (see Table 3). However, boom episodes since 1994 have tended to last one year less ( $4-5$ years). ${ }^{9}$

Across income groups, a significant proportion of credit boom episodes are associated with sustained growth rates of real credit per capita during the build-up phase of the boom (see Table 4). In the preceding 3 (5) years, between 50 to 70 (30 to 40) percent of credit boom episodes exhibited a growth rate of real credit per capita of at least 5 percent. The proportions are higher for low-income and upper-middle-income countries relative to lower-middleincome countries. Similar results obtain when the shorter time period of 1994-2011 is considered. We also find that around 80 percent of credit booms episodes identified for

\footnotetext{
${ }^{9}$ Similar qualitative results are obtained when fuel exports are excluded from the sample of countries (available upon request).
} 
middle income countries coincide in the two samples. However, this proportion is lower in the case of low-income countries (around 60 percent), with many new booms indentified after the global financial crisis. This suggests that the (long-run) trend of credit growth could have changed in recent years for low-income countries.

To check the robustness of our results, we also implemented the Mendoza and Terrones methodology using the credit-to-GDP ratio instead of real credit per capita. This allows us to relate credit developments to the size of the economy and account for the procyclicality of credit. Given the positive relationship between financial development and GDP growth, bank lending could, however, follow a positive trend, even when measured relative to GDP. Therefore, as noted by Barajas et al. (2009), credit booms need to be isolated as definite events separate from normal increments in the volume of credit. The correlation between the credit booms identified with real credit per capita and credit-to-GDP is around 50 percent (see Table 5). Appendix 4 presents the results with respect to incidence and duration. ${ }^{10}$

Table 5. Correlation between Credit Booms: Real Credit per Capita and Credit-to-GDP (Mendoza and Terrones' methodology)

\begin{tabular}{ccccc}
\hline & All countries & $\begin{array}{c}\text { Low-income } \\
\text { countries }\end{array}$ & $\begin{array}{c}\text { Lower-middle } \\
\text { income countries }\end{array}$ & $\begin{array}{c}\text { Upper-middle } \\
\text { income } \\
\text { countries }\end{array}$ \\
\hline Correlation since 1970 & 0.47 & 0.52 & 0.55 & 0.41 \\
Correlation since 1990 & 0.49 & 0.66 & 0.53 & 0.44 \\
\hline
\end{tabular}

\section{B. Behavior of Macroeconomic Variables around Credit Booms}

The event study analysis undertaken in this section examines the cyclical behavior of macroeconomic variables around the peak of credit boom episodes. In particular, seven-year event windows of the cyclical components of macro aggregates centered on the peak of credit booms $(t=0)$ are constructed for the three income groups. The event windows show the crosscountry means and medians of the cyclical components of output, investment, private and public consumption, non-tradable output, real exchange rate, broad money, external demand, the current account to GDP ratio and capital inflows to GDP ratio. ${ }^{11}$

\footnotetext{
${ }^{10}$ Appendix 4 also presents the results using Tornell and Westermann methodology for credit boom identification.

${ }^{11}$ All variables are in measured in constant prices, per-capita terms and de-trended using the HP filter, except for current account and capital inflows to GDP ratios (which are in current prices and not de-trended), and the real exchange rate. See Appendix 2 for details on variable definitions and sources. Given data constraints, we are unable to examine the cyclical properties of stock market and real estate prices for a large number of countries.
} 
Figure 2 shows the dynamic behavior of the cyclical components of key macroeconomic variables around the peak of credit boom episodes by income groups for the full sample. For lower-middle and upper-middle income countries, the dynamics of most variables exhibit a well-defined pattern around the peak of credit boom episodes: an increase during the expansionary phase and a decrease during the unwinding phase. While cyclical components of domestic demand variables show a well-defined pattern around credit booms, investment shows a larger expansion and subsequent contraction as compared to private and government consumption.

The results based on medians indicate that the current account ratio deteriorates during the build-up phase and improves as the boom unwinds. The real exchange rate appreciates by around 4 percent above-trend in the build-up phase and then drops to around 3 percent. Capital inflows, measured by the ratio of gross other investments to GDP, ${ }^{12}$ show a median above-trend increase of around one percentage point of GDP by $\mathrm{t}=-1$ (i.e., one period before the peak of the boom). ${ }^{13}$ Money balances (M2) exhibit an expansion in the build-up phase of up to 10 percentage points above trend, followed by a decline.

External demand, measured by the weighted average of GDP growth of country's trading partners, also exhibits a well-defined pattern around credit booms, reflecting the potential effects of external shocks on the domestic economy. Non-tradable output shows an expansion during the build-up phase (up to 5 percentage points above trend) and then a decline. The latter could reflect the fact that in an upturn, financing constraints ease for the non-tradable sector, possibly due to higher collateral values as discussed in financial accelerator models. Finally, while the amplitude of the cyclical fluctuations appears to be larger in upper-middle income compared to that observed in lower-middle countries, a normalization using the standard deviations of cyclical components to account for business cycle volatility indicates that the size of the amplitude is similar across income groups. The association between credit boom episodes and inflation rates and the terms-of-trade are, however, less clear cut (not reported here, but available upon request).

How similar or different are these dynamics for low-income countries? For the group of lowincome countries, the cyclical behavior of some macroeconomic aggregates exhibits a similar dynamics as to the one observed in middle-income countries. For instance, output shows a

\footnotetext{
${ }^{12}$ Following Calderón and Kubota (2012), gross inflows are used in the analysis because they provide a more precise measure of foreign financing flows. In the case of low- and lower-middle income countries, gross inflows (other investments) have been corrected for the implementation of HIPC debt relief. The category of other investments includes all financial transactions not covered under FDI, portfolio investments, financial derivatives or reserves assets (i.e., it comprises trade credits, cross-border bank loans, currency and deposits, and other assets/liabilities).

${ }^{13}$ An event study analysis was also performed using the ratio of gross total inflows including FDI and portfolio flows. We find that total inflows would show a clear dynamics for upper-middle income countries. For lowermiddle income countries, the median does not exhibit a clear dynamics, as this is largely influenced by the dynamics of the cyclical component of FDI.
} 
defined dynamics around the peak of the boom. However, among the domestic demand components, only investment exhibits an increase during the expansionary phase (of around 8 percentage point above trend), followed by a contraction during the unwinding phase. Furthermore, government expenditure is procyclical in the case of middle-income countries but there no discernible pattern can be gleaned in the case of low-income countries. No clear dynamics are evident in the case of consumption, possibly due to measurement issues.

The current account ratio exhibits a deterioration, mainly at the peak of the boom (time $t$ ), and after one year (i.e., at $t=1$ ). During the build-up phase, unlike in middle-income countries, the cyclical component is close to zero. Non-tradable output also shows an expansion during the build-up phase, but, unlike in middle-income countries, the maximum deviation from trend occurs one period before the peak of the boom $(t=-1)$. External demand still shows an above-trend expansion during the build-up phase, but declines before the peak of the boom. The capital inflows ratio does not show any dynamics around the boom episode, related, in part, to the high degree of heterogeneity within low-income countries in terms of their extent of financial integration, depth of the financial sector, and ease of access to credit. ${ }^{14}$ However, monetary expansions, related to monetary policy easing, relaxation of lending standards, or external demand shocks, fuel significant credit expansions in lowincome countries with a subsequent impact on investment and output. ${ }^{15,16}$

We also considered the dynamics of the macroeconomic variables based on the credit booms episodes identified since 1994. Most of the qualitative results are similar to the ones described for the full sample. However, there are a number of differences, as indicated in Figure 3: (i) the cyclical component of the real exchange rate only exhibits a clear dynamics in lower and upper-middle countries when looking at mean values of the cyclical component, (ii) real GDP does not show a clear dynamics for low-income countries, but private consumption and investment do, and (iii) cyclical components show larger deviations around the peak for private consumption and the current account to GDP ratio.

\footnotetext{
${ }^{14}$ This result is not entirely surprising; as of 2010, based on the index of capital account openness (Chinn-Ito), only 30 percent of low income countries ( 11 out of 32 countries in the sample) exhibited above-median values of the index.

${ }^{15}$ As a robustness check, the event study was also done excluding oil exporters, but the qualitative thrust of our results remained unchanged.

${ }^{16}$ As discussed in Mendoza and Terrones (2012), the event study analysis shows point estimates of the central tendency, but it does not demonstrate whether these results are statistically significant. To address this issue, we ran cross-section regression for many macroeconomic variables for three dates of event window (peak-1, peak, peak +1 ) on a constant using OLS regression. Appendix 5 shows the results. We find that many of the coefficients are statistically significant. However, some coefficients exhibit large standard errors (e.g. real GDP for low-income countries and real consumption for lower-middle income countries).
} 


\section{Potential Drivers of Credit Booms}

In this sub-section, we use frequency analysis to examine the association between credit boom episodes and pertinent variables that have been identified in the literature as triggers of credit booms. These include the role of: (i) surges in capital inflows, (ii) financial sector reform, and (iii) exchange rate regimes.

We first examine the relationship between credit boom episodes and surges in capital inflows. A rapid rise in capital inflows could lead to an increase in loanable funds, potentially weakening lending standards. We identify a capital inflows surge as of date $t$ when the preceding three-year average of the ratio of gross investments to GDP is above the median value for each income group. Table 6 shows the percentage of credit booms preceded by large capital inflows by income group. Between 30 and 44 percent of credit booms episodes were preceded by an increase in capital inflows. ${ }^{17}$ This proportion increases by income group, suggesting that increased capital inflows are an important driver of credit boom episodes in middle-income countries, but to a lesser extent in low-income countries. ${ }^{18}$

Table 7 shows the results of the frequency analysis for the association between credit boom episodes and exchange rate regimes (in place for the preceding three years). Five exchange regime groupings were created using Ilzetzki, Reinhart and Rogoff's (2011) classification: (i) fixed and managed; (ii) dirty floating; (iii) floating; (iv) mixed; and (v) rest. ${ }^{19}$ In line with empirical evidence for emerging market and advanced economies, credit boom episodes are most often observed under less flexible exchange rate regimes (Mendoza and Terrones, 2008 and Dell'Ariccia et al., 2012). We find that the proportion of credit booms under fixed or managed exchange rate regimes is 62 percent and 73 percent for lower-middle and uppermiddle countries, respectively. In the case of low-income countries this proportion is lower (46 percent). ${ }^{20}$ This result could be associated with the fact that, relative to low-income countries, middle-income countries are more exposed to surges in capital inflows. Indeed, Magud et al. (2011) document evidence suggesting that countries with less flexible exchange rates often experience significant credit expansions during surges in capital inflows, rendering them more vulnerable to capital flow reversals.

\footnotetext{
${ }^{17}$ Table 6 also presents the results using additional measures of capital inflows: one that includes foreign direct investment, portfolio inflows and other investments, and another that only includes portfolio inflows and other investments. The results are similar to the one when only the ratio of other investments is used.

${ }^{18}$ This result mainly reflects the fact that middle and high income countries receive most of the share of crossborder capital flows compared to low-income countries. Few low-income countries would have shown episodes of capital flow bonanzas during the last 30 years or so (see Reinhart and Reinhart, 2008).

${ }^{19}$ The mixed regime includes freely falling and dual market in which parallel market data is missing. The category "rest" includes countries that switched across the other regimes in any of the three years prior to the peak of the credit boom.

${ }^{20}$ Care is needed with the interpretation of this number given that many low-income countries belong to a monetary union.
} 
Finally, we examine whether financial liberalization serves as a trigger for credit booms. Financial deepening and liberalization can lead to an increase in credit aggregates, which if not accompanied by improvements in the financial supervisory and regulatory frameworks, could fuel financial instability. Financial liberalization is measured using the Abiad et al. (2008) index of financial reforms. ${ }^{21}$ We use a modified version of this index that excludes the banking supervision indicator. This is because while the rest of the components of the index measure the degree of financial liberalization, stronger banking supervision could serve to control unhealthy credit expansion. A country in each income group is identified as having an increase in its degree of financial liberalization as of time $t$ when the preceding three-year change of the modified index (change between $t-1$ and $t-3$ ) is above the median of its respective income group.

Our results indicate that around 22 percent of credit booms that occurred at date $t$ in lowincome countries are preceded by above-median increases in the financial liberalization index, as compared to 24 and 38 percent in the case of lower- and upper middle-income countries. $^{22,23}$. In particular, credit boom episodes prior to 1990 are largely associated with low quality of banking supervision (the lowest value of the index). The same pattern is observed when looking at credit booms since 1990. This suggests that financial liberalization and financial reforms may not necessarily go hand in hand with a prudent framework of banking regulation and supervision.

Table 8. Credit Booms and Banking Supervision

\begin{tabular}{ccccc}
\hline & \multicolumn{4}{c}{ Index of banking sector supervision $^{1 /}$} \\
\cline { 2 - 5 } & 0 & 1 & 2 & 3 \\
\hline $\begin{array}{c}\text { Number of booms associated with low/high } \\
\text { banking sector supervision }\end{array}$ & 34 & 11 & 6 & 2 \\
Percentage & 64 & 21 & 11 & 4 \\
$\begin{array}{c}\text { Number of booms, since 1990, associated } \\
\text { with low/high banking sector supervision } \\
\quad \text { Percentage }\end{array}$ & 11 & 11 & 6 & 2 \\
& 21 & 21 & 11 & 4 \\
\hline
\end{tabular}

${ }^{1 /}$ Index ranges between 0 (not regulated) and 3 (highly regulated), Abiad et al (2008)

\footnotetext{
${ }^{21}$ The index includes indicators of directed credit, credit ceilings, interest rate controls, banking supervision, entry barriers, privatization, capital mobility, and security markets, with higher index values denoting a more liberalized financial system.

${ }^{22}$ Care is needed in interpreting these results given that the index only has data for about 47 percent of our sample of countries (the index is available for 91 countries and covers the period from 1973 to 2005).

${ }^{23}$ This sub-index takes into account whether a country adopted risk-based capital adequacy ratios based on the Basle I capital accord, whether the banking supervisory agency is independent from the executive's influence and whether it has sufficient legal power, whether certain financial institutions are exempted from supervisory oversight and whether the on-site and off-site examinations of banks are effective or not (Abiad et al., 2008). The index ranges from 0 (not regulated) to 3 (highly regulated).
} 


\section{Empirical Analysis of the Incidence of Credit Boom}

Foreign flows (mostly cross-border bank flows and, to some extent, portfolio inflows) into low-income countries economies have surged in the post-crisis period. Although these increased foreign capital inflows may supplement domestic financing of investment, they also pose challenges. In particular, they could result in rapid credit expansion, overwhelming relatively shallow financial markets. In this section, we use regression analysis to bolster our findings from the event study and frequency analysis that capital inflows can predict the incidence of credit booms. Similar to Calderón and Kubota (2012), we estimate panel Probit models for our sample of countries for the period 1970 to 2011 . The dependent variable is a dummy variable that takes the value of 1 if a credit boom episode is observed, from start to end, and 0 otherwise.

As in the previous sections, we use the ratio of gross investments (excluding FDI) and gross other investments (excluding portfolio flows and FDI) as the two relevant measures of capital inflows. ${ }^{24}$ Control variables comprise credit growth, real GDP growth, inflation rates, the flexibility of the exchange rate regime, and the depth of the domestic financial system. ${ }^{25} \mathrm{We}$ also include variables that control for external shocks, such as growth in main trading partners (external demand), the terms-of-trade, and the U.S. federal funds rate to proxy for international liquidity conditions. ${ }^{26}$ Finally, we include a measure of trade openness to capture structural characteristics of the economy (see Appendix 2 for variable details). All explanatory variables are lagged.

Table 9 reports the results for the baseline regression with gross other investment flows (columns 1-3) and gross capital flows, excluding FDI, (columns 3-6) as relevant measures of capital inflows. We find that sustained growth in economic activity and private credit tend to be associated with a higher probability of credit boom episodes. Consistent with Dell'Ariccia et al. (2012), we find that financial system depth is also associated with a higher probability of credit booms. Regarding external shocks, the incidence of credit booms is positively associated with below-trend deviations of the U.S. federal funds rate (lagged). Although the sign of the estimated coefficients is as expected, we do not find robust evidence of an effect of inflation and growth in external demand or in the country-specific terms-of-trade on the incidence of credit booms.

Importantly, our Probit analysis confirms that countries with larger capital inflows are more likely to experience credit booms. Specifically, we find that the second year lag of this ratio

\footnotetext{
${ }^{24} \mathrm{We}$ also considered alternative specifications, including the ratio of net investment liabilities to GDP.

${ }^{25}$ Exchange rate flexibility is proxied by the exchange rate regime classification developed by Reinhart and Rogoff (2004), and updated by Ilzetzky, Reinhart, and Rogoff (2011). The degree of flexibility ranges from 1 (no separate legal tender) to 13 (free floating).

${ }^{26} \mathrm{We}$ include the cyclical component of the U.S. federal funds rate (deviation from trend generated using the HP filter).
} 
has a positive and significant effect on the incidence of credit booms. To provide an economic interpretation of the above results, we use the marginal effects from the estimation in column (1) of Table 9 to assess the contribution of explanatory variables to the probability of a credit boom. Table 10 presents the marginal effects and Figure 4 presents the percentage increase in the probability of experiencing a credit boom when the explanatory variables increase in value compared to its sample median. For example, if the ratio of gross investments increases to around 20 percent of GDP, from its median value in the sample of around 2 percent, the probability of a credit boom increases by about 40 percent.

Table 10. Marginal Effects Evaluated at Medians

\begin{tabular}{lcccl}
\hline & Coefficient & $\begin{array}{c}\text { Standard } \\
\text { error }\end{array}$ & P-value & \\
\hline Gross other investments/GDP & 0.11 & 0.06 & $0.066^{*}$ \\
Private sector credit/GDP & 0.18 & 0.04 & $0.00{ }^{* * *}$ \\
GDP growth rate & 0.25 & 0.11 & $0.02 \quad * *$ \\
Growth rate of private sector credit-to- & & & & \\
GDP & 0.18 & 0.04 & $0.00^{* * *}$ \\
\hline
\end{tabular}

${ }^{1 /}$ Marginal effects obtained from specification [1] in Table 9.

Figure 4. Increase in the Probability of a Credit Boom
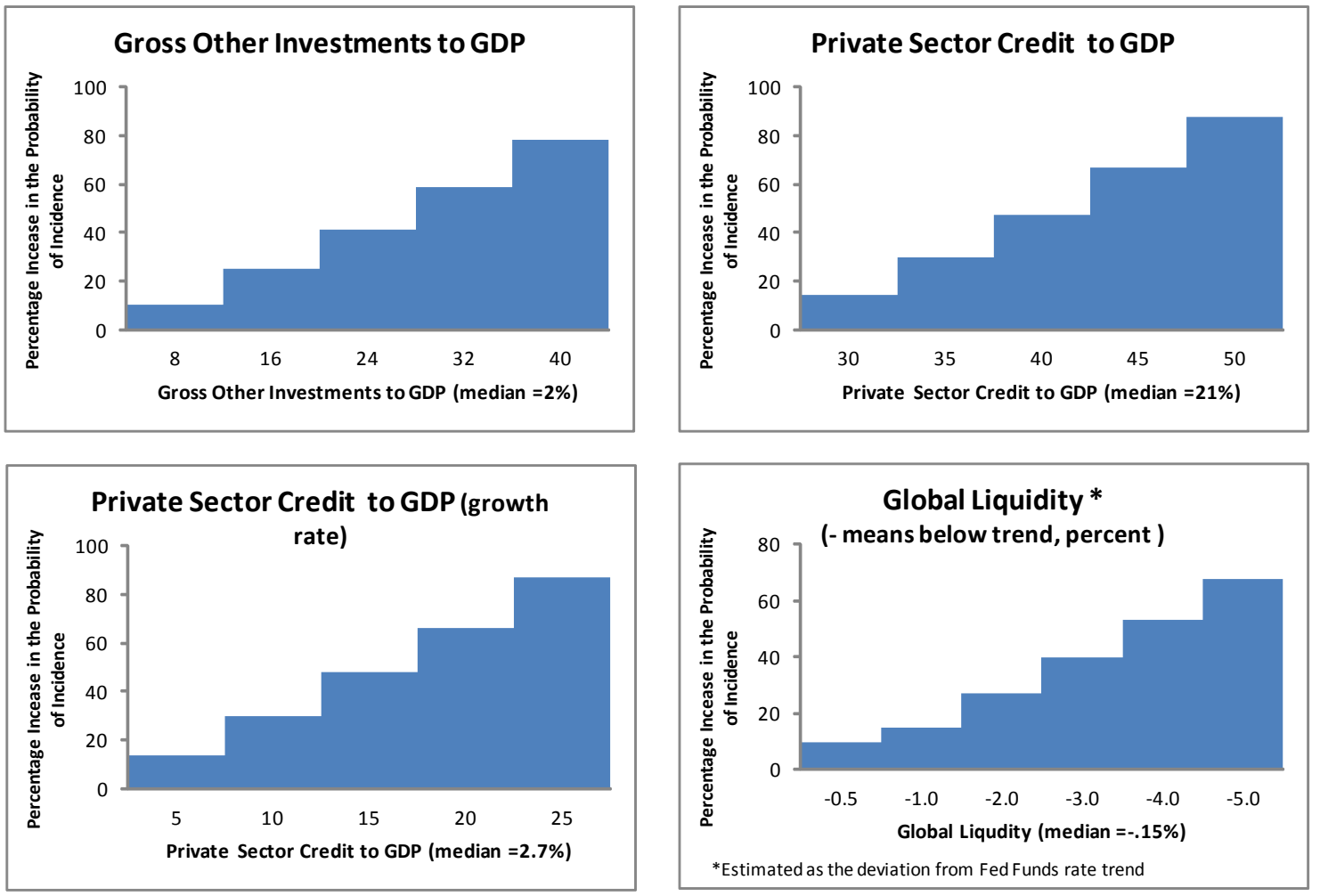
Our Probit analysis confirms countries with larger capital inflows are more likely to experience credit booms. This result is robust to variation in the choice of sample countries, the criteria to define credit booms and alternative explanatory variables (not reported here, but available upon request). Appendix 6 presents the results for the specifications included in Table 9 using the ratio of net other investments to GDP. As before, the ratio of net other investments is positively associated with the incidence of credit boom episodes. The results for the remainder of the explanatory variables are similar to the ones presented in Table 9.

Finally, financial reforms have been identified in the literature as a potential driver of credit boom episodes. As discussed in Decressin and Terrones (2011), periods of financial liberalization tend to spur credit growth. Using the comprehensive index of financial reforms developed by Abiad, Detragiache and Tressel (2008), we test the impact of financial reforms on the incidence of credit booms. In addition, we separately examine the potential impact of banking supervision and prudential regulations on the probability of credit booms. Appendix 7 presents the regression results including these reform indexes. While the sign of the coefficients point in the right direction (financial reforms increase the probability of credit booms and better banking supervision and prudential regulations decrease the probability of credit booms), they are not statistically significant. An important caveat is that the indeces have limited coverage for our sample of countries (covering only 60 countries in our sample, and reducing our country-year observations by half).

\section{Credit Booms, Banking Crisis, ANd Financial DeEpening}

\section{A. Credit Boom Episodes and Banking Crises}

The literature on credit booms suggests that while most banking crisis has been preceded by a credit boom episode, not all credit boom episodes were followed by, or ended in a banking crisis. Using the banking crisis data reported in Laeven and Valencia (2012), we find that 23 out of the 111 credit boom episodes in our sample were associated with a banking crisis. ${ }^{27}$ Most of these episodes occurred in upper-middle income countries (50 percent) and lowermiddle income countries ( 25 percent). Around 10 percent of these episodes occurred in lowincome countries. ${ }^{28}$

\footnotetext{
${ }^{27}$ A credit boom episode is associated with a banking crisis if the start of the banking crisis, as dated by Laeven and Valencia, occurs between the peak year of the credit boom until two years after the end of the credit booms. The authors define a banking crisis as systemic if two conditions are met: (i) significant signs of financial distress in the banking system (as indicated by significant bank runs, losses in the banking system, and/or bank liquidations) and (ii) significant banking policy intervention measures in response to significant losses in the banking system (extensive liquidity support, bank restructuring gross costs, significant bank nationalizations, significant guarantees put in place, deposit freezes and/or bank holidays).

${ }^{28}$ The Laeven and Valencia database documents 28 banking crisis for the group of low-income countries between 1970 and 2011; half of these occurred in the eighties.
} 
A key question is whether credit booms associated with banking crises exhibit distinct characteristics compared to credit booms that do not end up in a banking crisis. If this is the case, policymakers could use this information to distinguish between booms stemming from beneficial financial deepening from those portending macroeconomic and financial instability. When analyzing the duration of credit booms, we find that around half of the credit booms associated with a banking crisis last for over six years compared to 25 percent in the case of booms that did not end up in a banking crisis. This suggests that credit booms that last longer have a higher probability of being associated with a banking crisis.

With respect to the depth of the financial sector at the beginning of the credit boom, the median ratio of private credit to GDP is about 25 percent for the booms associated with banking crises compared to about 19 percent for other booms. Finally, the median expansion in the credit-to-GDP ratio during the credit boom is higher (about 15 percent) for the booms associated with banking crises, compared to 9 percent for other booms.

Table 11. Characteristics of Credit Booms Associated with Banking Crisis

\begin{tabular}{|c|c|c|c|c|}
\hline & \multicolumn{2}{|c|}{ Booms associated with banking crises } & \multicolumn{2}{|c|}{ Booms not associated with banking crises } \\
\hline All income groups & Median & Mean & Median & Mean \\
\hline Duration (in years) & 6.0 & 6.4 & $6.0^{3 /}$ & 5.6 \\
\hline Credit-to-GDP ratio $(\%)^{1 / 1}$ & 25 & 29 & 19 & 24 \\
\hline $\begin{array}{l}\text { Expansion in the Credit-to- } \\
\text { GDP ratio }(\%)^{2 /}\end{array}$ & 15 & 38 & 9 & 22 \\
\hline
\end{tabular}

Do macroeconomic aggregates exhibit different cyclical behavior during credit booms associated with banking crises? To address this question, we performed an event study analysis to compare fluctuations in credit and macro-aggregates between the different booms episodes (see Figure 5). Focusing on medians, the analysis indicates that most of the macroeconomic variables exhibit a well-defined pattern around the boom episodes associated with banking crises. Moreover, macroeconomic fluctuations are larger and display more abrupt declines (or increase in the case of the current account ratio) than those observed in booms that did not end up in a banking crises. ${ }^{29}$

Interestingly, the cyclical component for most variables is above their trend at least 3 years before the peak of the credit boom (below-trend for the current account ratio) for episodes associated with banking crises. This reflects an accumulation of potential imbalances in the upswing phase. This result is particularly striking when examining the deterioration in the current account ratio, real exchange rate appreciation, and increase in capital inflows. In the case of capital inflows, the cyclical component rises in the upswing of the crisis episodes and falls in the downswing, but is more stable in the non-crisis episodes.

\footnotetext{
${ }^{29}$ This result is consistent with the one presented in Mendoza and Terrones (2012) for their sample of emerging market and advanced economies.
} 


\section{B. Credit Booms and Financial Deepening}

Do credit booms not associated with banking crises end up in a soft landing? As discussed by Tornell and Wetermann (2002), not all credit booms reflect excessive risk taking, and could be reflective of more benign financial deepening. In this case, credit booms should be associated with permanent take-offs in the credit to GDP ratio. In other words, it would be less likely to have a reversion to a lower level of financial depth than observed before the start of the credit boom episode (Gourinchas, et al., 2002).

In our sample, three quarters of credit booms not associated with banking crises exhibit an increase in the level of financial depth (as measured by the level of real credit per capita) by the end of the boom episode. This proportion decreases to about seventy percent two years after the end of the boom episode (see Table 12). For low-income countries, the proportion is between 63 and 71 percent. ${ }^{30}$ This analysis was also performed using using the ratio of credit to GDP to define the credit boom episode (Appendix 4). The results show that 70 percent of the credit booms episodes not associated with banking crises exhibit an increase in the level of credit to GDP two year after the end of the boom episode. The majority of credit booms that have not been associated with either higher banking crises or financial depth occurred in the context of a downward trend in financial intermediation, often related to periods of macroeconomic distress (particularly during the eighties and early nineties). ${ }^{31}$

\section{Table 12. Proportion of Credit Booms Associated with Higher Financial Depth by the End of the Boom Episode}

\begin{tabular}{|c|c|c|c|}
\hline & $\begin{array}{c}\text { End of the credit } \\
\text { boom }^{1 /}\end{array}$ & $\begin{array}{c}\text { End of the credit boom } \\
+ \text { one year }^{2 /}\end{array}$ & $\begin{array}{c}\text { End of the credit boom } \\
+ \text { two years }\end{array}$ \\
\hline All income groups & 76 & 70 & 67 \\
\hline Low-income countries & 70 & 71 & 63 \\
\hline $\begin{array}{c}\text { Excluding low-income } \\
\text { countries }\end{array}$ & 78 & 72 & 68 \\
\hline
\end{tabular}

${ }^{2 /}$ Average of real credit per capita between time $t$ and time $t+1$.

${ }^{3 /}$ Average of real credit per capita from time $t$ to time $t+2$.

\footnotetext{
${ }^{30}$ Most credit booms not associated with banking crises that occurred since 1993 are associated with financial deepening. However, for credit booms that have ended in recent years, it may be difficult to assess whether these have introduced vulnerabilities in the banking sector.

${ }^{31}$ Around 70 percent of these credit booms occurred before 1993.
} 
To what extent can we assess if credit expansion is associated with financial deepening? Barajas et al. (2013) develop the concept of a financial possibility frontier as a constrained optimum level of financial development. Their analysis points to the importance of gauging the relative performance of the financial sector by taking into account structural country characteristics, institutional, and macroeconomic factors that have a bearing on financial deepening.

This concept is made operational through a benchmarking exercise which relates the actual level of financial deepening to levels predicted by structural and macroeconomic characteristics. In particular, the predicted level of financial deepening is estimated by regressing an indicator of financial deepening (real credit per capita) against structural factors such as GDP per capita, population (to proxy for market size), population density (to proxy for the ease of service provision), age dependency ratio (to control for demographic trends and corresponding saving behavior). Dummy variables are included to capture other potential factors (off-shore center, transition country, oil-exporter) and time effects. ${ }^{32} \mathrm{We}$ perform the regression for our sample of countries and for the period 1970-2011 using pooled OLS regressions. The regression results are used to predict the benchmark level of financial deepening for each country in each year for which data is available (see Table 13 for the regression results).

Using this approach, consistent with Barajas et al. (2013), we find that large negative changes in the gap between actual credit growth and the benchmark level, are associated with a higher likelihood of boom episodes. Moreover, we find that about 80 percent of credit booms associated with banking crises took place when levels of real credit per capita were well above the levels predicted by structural and macroeconomic fundamentals. This suggests that in addition to the dynamics of macroeconomic aggregates discussed in the previous section, the benchmarking analysis could provide useful information regarding a potentially unsustainable credit expansion.

\section{Conclusions}

Earlier studies on credit booms have mainly focused on emerging market and advanced economies. This study documents stylized facts on credit booms and the macroeconomic dynamics around boom episodes in low- and middle-income countries. In addition, we examine whether credit booms associated with banking crises exhibit distinct patterns compared to other types of credit booms. Such an analysis can provide valuable lessons for low-income countries given the rapid increase in credit experienced in recent years.

\footnotetext{
${ }^{32}$ Additional regressions (not reported here) included inflation, GDP per capita growth, and an indicator or exchange rate classification as controls.
} 
What lessons can then be drawn from the experiences of middle-income countries? First, our analysis suggests that while the duration and magnitude of credit booms in low-countries share broadly similar characteristics with middle income countries, the behavior of macroeconomic aggregates differs. But as low-income countries develop, they should be mindful of the cyclical behavior of output, investment, private and public consumption, real exchange rate, broad money, external demand, the current account and capital inflows to GDP ratios as these tend to exhibit clear dynamics for middle-income countries: a significant increase during the expansionary phase and a decrease during the unwinding phase. From a policy perspective, our results suggest that monitoring the duration and magnitude (deviation from trend) of credit expansion together with the cyclical behavior of pertinent macroeconomic variables could be useful. In particular, large and longer deviations from trend can serve as a signal of an unsustainable build-up of imbalances.

Second, our frequency and empirical analyses suggest that capital inflows are important drivers of credit boom episodes. Indeed, our empirical results corroborate the importance of capital inflows as significant predictors of credit booms. Moreover, the frequency analysis suggests that countries with less flexible exchange rates can experience significant credit expansions during surges in capital inflows, potentially rendering them more vulnerable to capital flow reversals. Country experiences also indicate that financial liberalization can trigger credit booms, as reforms may not occur in tandem with a prudent framework of banking regulation. Taken together, these findings suggest that low-income countries should be mindful of the inter-linkages between financial liberalization and increased cross-border banking activities, and the capacity to cope with large inflows.

We further find that credit booms associated with banking crises not only exhibit distinct macroeconomic dynamics around the peak of boom episodes but also reflect a potentially large deviation of credit from country fundamentals. In particular, we find that macroeconomic fluctuations in crisis episodes tend to be larger and display more abrupt declines than those observed in non-crisis episodes. That said, it is difficult to predict credit booms, as causality is often difficult to establish, and distinguishing booms from beneficial financial deepening is often fraught with challenges. In this context, our analysis suggests the credit growth in a majority of boom episodes associated with banking crises ( 80 percent) was above levels consistent with structural factors and other country fundamentals. This suggests that comparing the observed level of financial deepening with levels predicted by structural fundamentals could provide a useful gauge of a potentially unsustainable credit expansion.

More generally, as low-income countries become more financially interconnected and reliance on external funding sources increases, it would be important to hedge against potential currency, maturity and any balance sheet mismatches. Imposing limits on net foreign open positions consistent with the pace of financial deepening, ensuring that financial institutions do not rely solely on short-term funding or increasing capital risk weights on volatile funding sources, mitigating high credit risk stemming from rapid credit expansion (e.g. proper provisioning standards, tightening definitions of NPLs), and strengthening 
banking supervision (e.g. increasing on-site audits, monitoring vulnerabilities related to cross-border funding) are examples of policies that could help mitigate unsustainable credit expansions. Such policies would also allow low-income countries to undergo much-needed financial deepening in line with their macroeconomic fundamentals. 


\section{REFERENCES}

Abiad, Abdul, Erica Detragiache, and Thierry Tressel, 2008, "A New Database of Financial Reforms," IMF Working Paper No. 08/266.

Barajas, Adolfo, Giovanni Dell'Ariccia, and Andrei Levchenko, 2009, "Credit Booms: The Good, the Bad, and the Ugly," Unpublished manuscript, International Monetary Fund (Washington, DC).

Barajas, Adolfo, Thorsten Beck, Era Dabla-Norris, and Seyed Reza Yousefi, 2013, "Too Cold, Too Hot, Or Just Right? Assessing Financial Sector Development Across the Globe," IMF Working Paper No. 13/81.

Borio, Claudio, and Philippe Lowe, 2002, “Assets Prices, Financial and Monetary Stability: Exploring the Nexus,” BIS Working Paper No. 114 (Basel: Bank for International Settlements).

Borio, Claudio and Mathias Drehmann, 2009, "Assessing the Risk of Banking Crises Revisited," BIS Quarterly Review, March, pp. 29-46.

Calderón, Cesar and Megumi Kubota, 2012, "Gross inflows gone wild: gross capital inflows, credit booms and crises," World Bank Policy Research Working Paper No. 6270.

Chinn, Menzie and Hiro Ito, 2006, “"What Matters for Financial Development? Capital Controls, Institutions, and Interactions," Journal of Development Economics, Volume 81, Issue 1, Pages 163-192 (October). Database updated until 2011 http://web.pdx.edu/ ito/Chinn-Ito_website.htm

Claessens, Stijn, Mayhan Kose, and Marco Terrones, 2011, "Financial Cycles: What? How? When?" IMF Working Paper No. 11/76.

Collyns, Charles and Abdelhak Senhadji. 2002. "Lending Booms, Real Estate Bubbles, and the Asian Financial Crisis.” IMF Working Paper No. 02/20.

Decressin, Jörg and Marco Terrones, 2011, "Credit Boom-Bust Cycles: Their Triggers and Policy Implications,” World Economic Outlook September 2011: Slowing Growth, Rising Risks, Chapter 1, Box 1.2."

Dell'Ariccia, Giovanni, Deniz Igan, Luc Laeven, and Hui Tong, 2012, "Policies for Macrofinancial Stability: How to Deal with Credit Booms," IMF Staff Discussion Note, $12 / 06$.

Gourinchas, Pierre-Olivier, Rodrigo Valdes and Oscar Landerretche, 2001, "Lending Booms: Latin America and the World," Economia, Volume 1, No 2, Spring, pp. 47-99.

IMF, 2012, "Enhancing Financial Sector Surveillance in Low-Income Countries: Financial Deepening and Macro-Stability."

Ilzetzki, Ethan, Carmen Reinhart, and Kenneth Rogoff, 2011,"The Country Chronologies and Background Material to Exchange Rate Arrangements into the 21st Century: Will the Anchor Currency Hold?” http://personal.lse.ac.uk/ilzetzki/index.htm/

Laeven, Luc and Fabian Valencia. 2012, "Resolution of Banking Crises: The Good, the Bad, and the Ugly," IMF Working Paper 12/163. 
Mitra Srobona, JaromírBenes, Silvia Iorgova, Kasper Lund-Jensen, Christian Schmieder, and Tiago Severo. 2011, "Toward Operationalizing Macroprudential Policies: When to Act?" Chapter 3 in Global Financial Stability Report, September (Washington, DC: International Monetary Fund)

Magud, Nicolas, Carmen Reinhart, and Esteban Vesperoni. 2012, "Capital Inflows, Exchange Rate Flexibility, and Credit Booms.” IMF Working Paper 12/41.

Mendoza, Enrique and Marco Terrones, 2008, "An Anatomy of Credit Booms: Evidence from Macro Aggregates and Micro Data,” NBER Working Paper No. 14049.

Mendoza, Enrique and Marco Terrones, 2012, "An Anatomy of Credit Booms and their Demise," NBER Working Paper No. 18379. , 2008, “An Anatomy of Credit Booms: Evidence from Macro Aggregates and Micro Data," NBER Working Paper No. 14049.

Reinhart, Carmen and Vincent Reinhart, 2008, "Capital Flow Bonanzas: An Encompassing View of the Past and Present," NBER Working Paper No. 14321.

Reinhart, Carmen and Kenneth Rogoff, 2009, “This Time is Different: Eight Centuries of Financial Folly," Princeton: Princeton University Press.

Schularick, Moritz and Alan Taylor. 2012, "Credit Booms Gone Bust: Monetary Policy, Leverage Cycles, and Financial Crises, 1870-2008," American Economic Review, vol. 102 , issue 2, pp.1029-61.

Tornell, Aaron and Frank Westermann, 2002, "Boom-Bust Cycles in Middle Income Countries: Facts and Explanation,” IMF Staff Papers, Vol. 49, Special Issue. 


\section{TABLES AND FIGURES}

Table 1. Number of Credit Booms Episodes: Using Real Credit per capita Methodology: Mendoza and Terrones (2012)

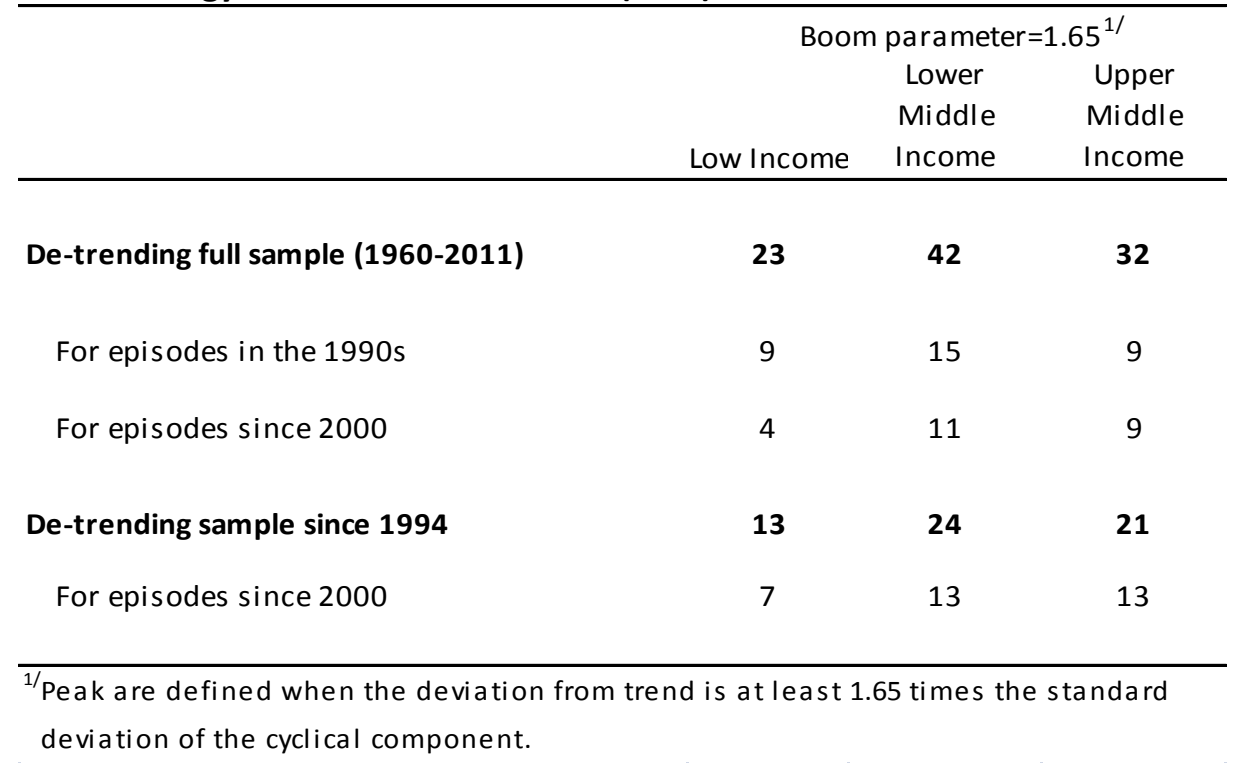

Table 2. Credit Boom Magnitudes: Income Group Summary Statistics

\begin{tabular}{|c|c|c|c|c|c|c|}
\hline \multirow[t]{2}{*}{ Categories } & \multicolumn{3}{|c|}{ Deviation from trend at peak } & \multicolumn{3}{|c|}{ Deviation from trend at peak/Std. Dev. of credit } \\
\hline & Low income & $\begin{array}{l}\text { Lower- } \\
\text { middle } \\
\text { income }\end{array}$ & $\begin{array}{c}\text { Upper-middle } \\
\text { income }\end{array}$ & Low income & $\begin{array}{c}\text { Lower-middle } \\
\text { income }\end{array}$ & $\begin{array}{c}\text { Upper-middle } \\
\text { income }\end{array}$ \\
\hline \multicolumn{7}{|c|}{ De-trending full sample (1960-2011) } \\
\hline Mean & 0.338 & 0.300 & 0.321 & 2.007 & 2.057 & 2.066 \\
\hline Median & 0.327 & 0.323 & 0.283 & 1.967 & 2.000 & 1.974 \\
\hline Std. Dev & 0.154 & 0.124 & 0.164 & & & \\
\hline Obs. & 23 & 42 & 32 & 23 & 42 & 32 \\
\hline \multicolumn{7}{|c|}{ De-trending sample since 1994} \\
\hline Mean & 0.211 & 0.283 & 0.272 & 1.469 & 1.807 & 1.701 \\
\hline Median & 0.163 & 0.261 & 0.266 & 1.533 & 1.901 & 1.762 \\
\hline Std. Dev & 0.131 & 0.120 & 0.165 & & & \\
\hline Obs. & 13 & 24 & 21 & 13 & 24 & 21 \\
\hline
\end{tabular}


Table 3. Duration of Credit Boom Episodes (years): Using Real Credit per capita

Methodology: Mendoza and Terrones (2012)

\begin{tabular}{|c|c|c|c|c|c|c|c|c|c|c|c|c|}
\hline & \multicolumn{6}{|c|}{ A. Mean } & \multicolumn{6}{|c|}{ B. Median } \\
\hline & \multicolumn{3}{|c|}{$\begin{array}{c}\text { Duration parameter }=0.25^{1 /} \\
\text { Boom parameter }=1.65\end{array}$} & \multicolumn{3}{|c|}{$\begin{array}{c}\text { Duration parameter }=0.75^{2 /} \\
\text { Boom parameter }=1.65\end{array}$} & \multicolumn{3}{|c|}{$\begin{array}{c}\text { Duration parameter }=0.25 \text {, } \\
\text { Boom parameter }=1.65\end{array}$} & \multicolumn{3}{|c|}{$\begin{array}{c}\text { Duration parameter }=0.75^{2 /}, \\
\text { Boom parameter }=1.65\end{array}$} \\
\hline & $\begin{array}{c}\text { Low } \\
\text { income }\end{array}$ & $\begin{array}{l}\text { Lower- } \\
\text { middle } \\
\text { income }\end{array}$ & $\begin{array}{l}\text { Upper- } \\
\text { middle } \\
\text { income }\end{array}$ & $\begin{array}{c}\text { Low } \\
\text { income }\end{array}$ & $\begin{array}{l}\text { Lower- } \\
\text { middle } \\
\text { income }\end{array}$ & $\begin{array}{l}\text { Upper- } \\
\text { middle } \\
\text { income }\end{array}$ & $\begin{array}{c}\text { Low } \\
\text { income }\end{array}$ & $\begin{array}{l}\text { Lower- } \\
\text { middle } \\
\text { income }\end{array}$ & $\begin{array}{l}\text { Upper- } \\
\text { middle } \\
\text { income }\end{array}$ & $\begin{array}{c}\text { Low } \\
\text { income }\end{array}$ & $\begin{array}{l}\text { Lower- } \\
\text { middle } \\
\text { income }\end{array}$ & $\begin{array}{l}\text { Upper- } \\
\text { middle } \\
\text { income }\end{array}$ \\
\hline De-trending full sample (1960-2011) & 6.3 & 5.8 & 5.6 & 5.8 & 5.4 & 5.1 & 6.0 & 6.0 & 6.0 & 6.0 & 5.0 & 5.0 \\
\hline For episodes in the 1990s & 6.3 & 5.9 & 5.9 & 6.1 & 5.5 & 5.2 & 6.0 & 5.0 & 6.0 & 6.0 & 5.0 & 5.0 \\
\hline For episodes since 2000 & 5.0 & 5.3 & 5.3 & 4.3 & 4.7 & 5.2 & 5.0 & 5.0 & 5.0 & 4.0 & 5.0 & 5.0 \\
\hline De-trending sample since 1994 & 4.5 & 4.6 & 5.1 & 4.0 & 4.0 & 4.6 & 4.0 & 4.5 & 5.0 & 4.0 & 4.0 & 4.0 \\
\hline For episodes since 2000 & 4.4 & 4.7 & 5.3 & 3.9 & 4.0 & 5.0 & 5.0 & 5.0 & 5.0 & 4.0 & 4.0 & 5.0 \\
\hline
\end{tabular}

${ }^{1 /}$ Start and end of the boom episodes are defined when the deviation from trend is 0.25 times the standard deviation of the cyclical component.

${ }^{2 /}$ Start and end of the boom episodes are defined when the deviation from trend is 0.75 times the standard deviation of the cyclical component. 
Table 4. Credit Boom Episodes and Periods of Sustained Credit Growth

\begin{tabular}{|c|c|c|c|c|c|}
\hline & \multirow{2}{*}{$\begin{array}{c}\text { Boom } \\
\text { parameter }=1.65 \\
\text { Low income }\end{array}$} & \multicolumn{2}{|c|}{$\begin{array}{c}\text { Number of Booms Episodes } \\
\text { where the growth rate of real } \\
\text { credit percapita was at least } 5 \\
\text { percent for the last... }\end{array}$} & \multicolumn{2}{|c|}{$\begin{array}{c}\text { Number of Booms Episodes } \\
\text { where the growth rate of real } \\
\text { credit percapita was at least } 10 \\
\text { percent for the last... }\end{array}$} \\
\hline & & 3 years & 5 years & 3 years & 5 years \\
\hline De-trending full sample (1960-2011) & 23 & 15 & 5 & 9 & 2 \\
\hline For episodes in the $1990 \mathrm{~s}$ & 9 & 4 & 1 & 3 & 1 \\
\hline For episodes since 2000 & 4 & 3 & 1 & 1 & 0 \\
\hline De-trending sample since 1994 & 13 & 5 & 2 & 3 & 1 \\
\hline \multirow[t]{3}{*}{ For episodes since 2000} & 7 & 4 & 2 & 2 & 1 \\
\hline & $\begin{array}{c}\text { Boom } \\
\text { parameter }=1.65\end{array}$ & \multicolumn{2}{|c|}{$\begin{array}{c}\text { Number of Booms Episodes } \\
\text { where the growth rate of real } \\
\text { credit percapita was at least } 5 \\
\text { percent for the last... }\end{array}$} & \multicolumn{2}{|c|}{$\begin{array}{c}\text { Number of Booms Episodes } \\
\text { where the growth rate of real } \\
\text { credit percapita was at least } 10 \\
\text { percent for the last... }\end{array}$} \\
\hline & Lower-middle income & 3 years & 5 years & 3 years & 5 years \\
\hline De-trending full sample (1960-2011) & 42 & 21 & 10 & 14 & 7 \\
\hline For episodes in the $1990 \mathrm{~s}$ & 15 & 6 & 2 & 4 & 2 \\
\hline For episodes since 2000 & 11 & 9 & 4 & 7 & 4 \\
\hline De-trending sample since 1994 & 24 & 16 & 6 & 11 & 5 \\
\hline \multirow[t]{3}{*}{ For episodes since 2000} & 13 & 10 & 3 & 7 & 3 \\
\hline & $\begin{array}{c}\text { Boom } \\
\text { parameter }=1.65\end{array}$ & \multicolumn{2}{|c|}{$\begin{array}{c}\text { Number of Booms Episodes } \\
\text { where the growth rate of real } \\
\text { credit percapita was at least } 5 \\
\text { percent for the last... }\end{array}$} & \multicolumn{2}{|c|}{$\begin{array}{c}\text { Number of Booms Episodes } \\
\text { where the growth rate of real } \\
\text { credit percapita was at least } 10 \\
\text { percent for the last... }\end{array}$} \\
\hline & Upper-middle income & 3 years & 5 years & 3 years & 5 years \\
\hline De-trending full sample (1960-2011) & 32 & 22 & 15 & 12 & 4 \\
\hline For episodes in the $1990 \mathrm{~s}$ & 9 & 6 & 4 & 5 & 1 \\
\hline For episodes since 2000 & 9 & 8 & 5 & 5 & 2 \\
\hline De-trending sample since 1994 & 21 & 16 & 9 & 12 & 2 \\
\hline For episodes since 2000 & 13 & 11 & 7 & 8 & 2 \\
\hline
\end{tabular}


Figure 2. Credit Booms, Economic Activity and Domestic Demand

(Cross country means and medians of cyclical components. Based on credit booms identified when de-trending is done over the full sample)

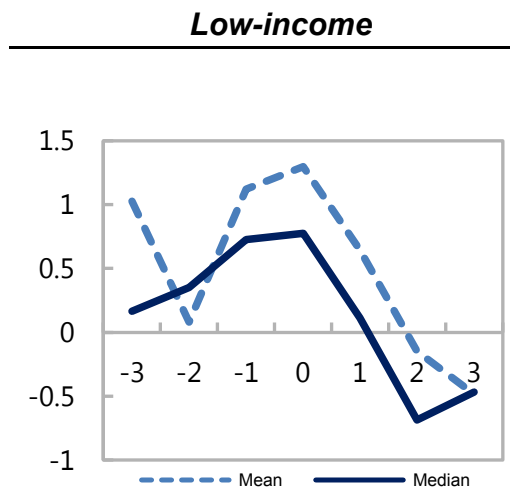

Real GDP

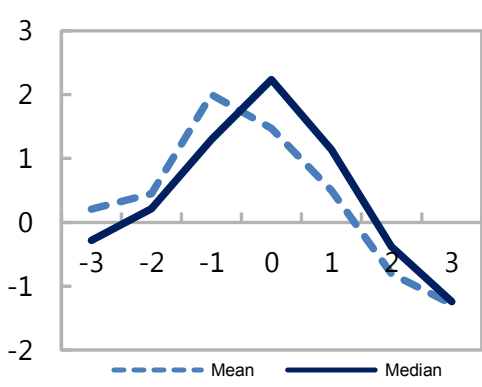

Real Consumption
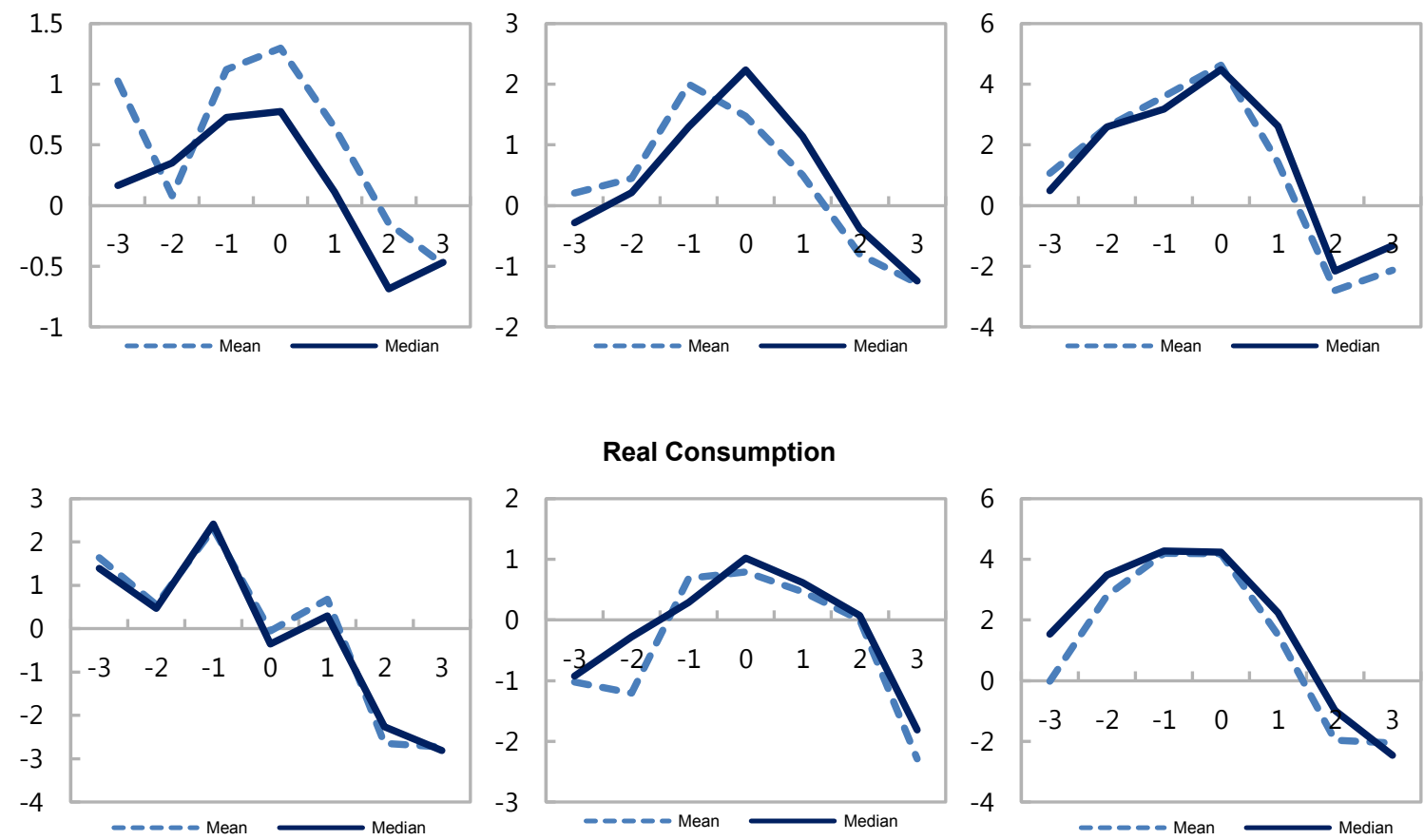
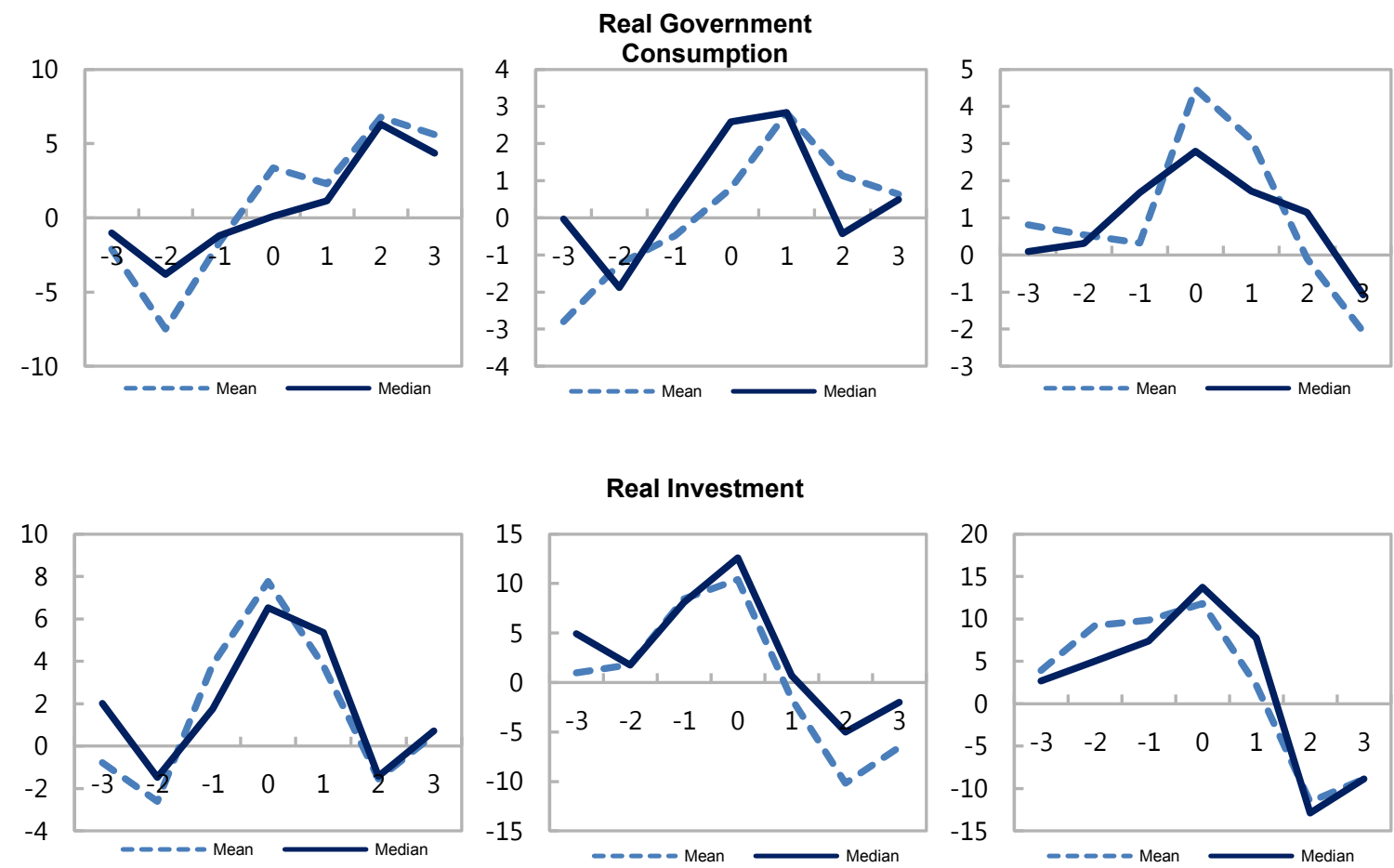

CInternational Monetary Fund. Not for Redistribution 
Figure 2 (cont'd). Credit Booms, Non-Tradable Output, Real Exchange Rate, and External Demand

(Cross country means and medians of cyclical components. Based on credit booms identified when de-trending is done over the full sample)

Non-tradables Output
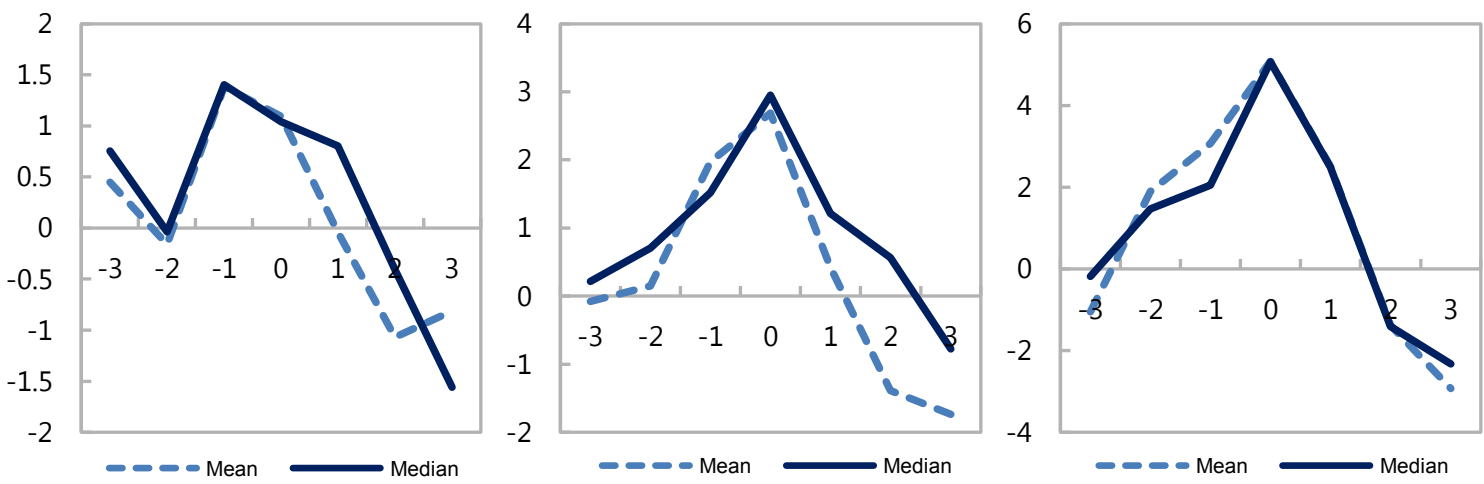

Real Exchange Rate
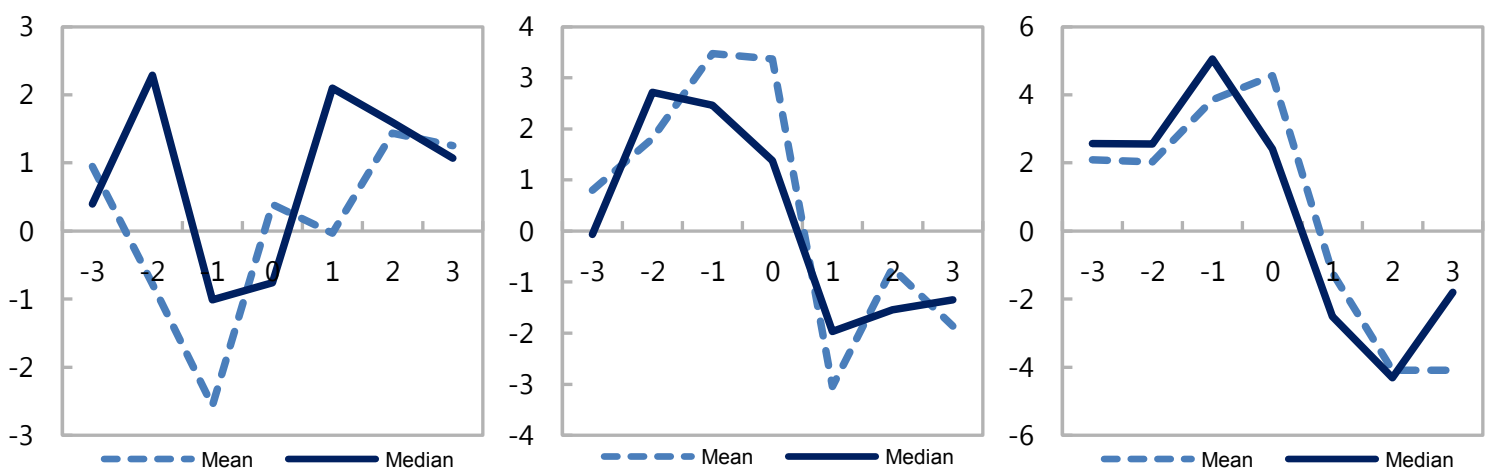

External Demand
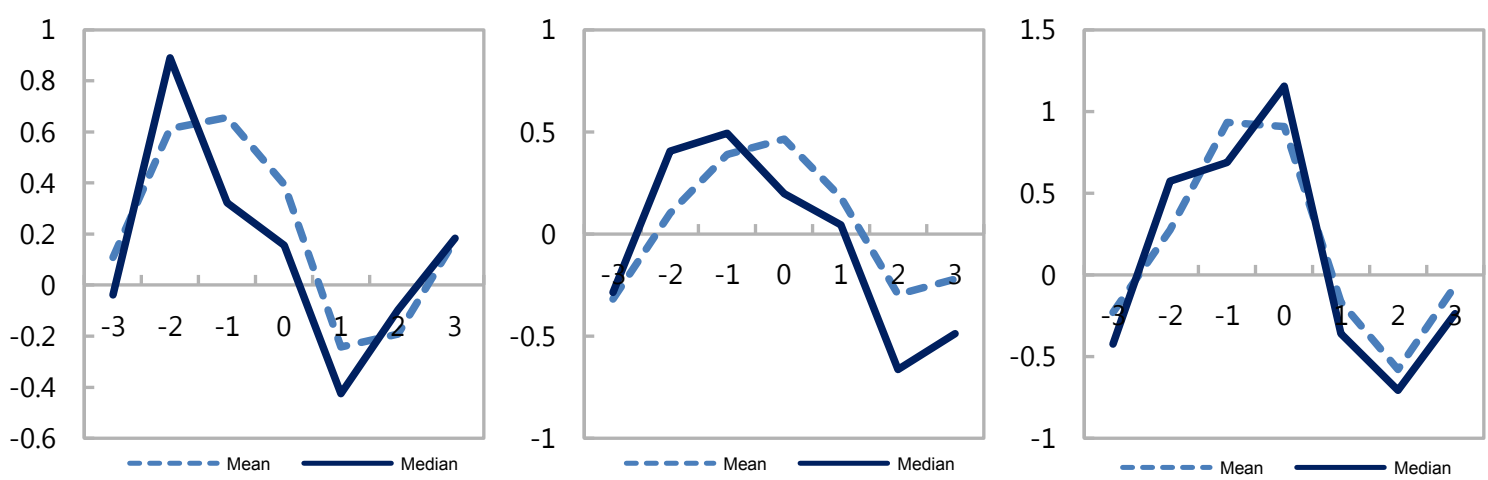
Figure 2 (cont'd). Credit Booms, Capital Inflows, Current Account, and Money

(Cross country means and medians of cyclical components. Based on credit booms identified when de-trending is done over the full sample)

Low-income Lower-middle income Upper-middle income

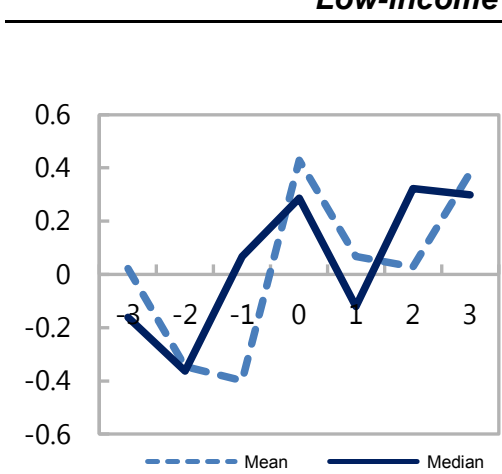

Other investments to GDP
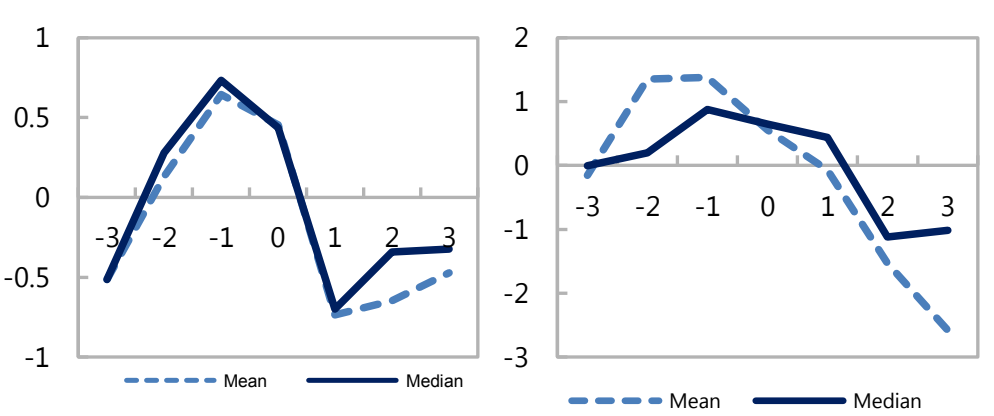

Capital Inflows ${ }^{1 /}$
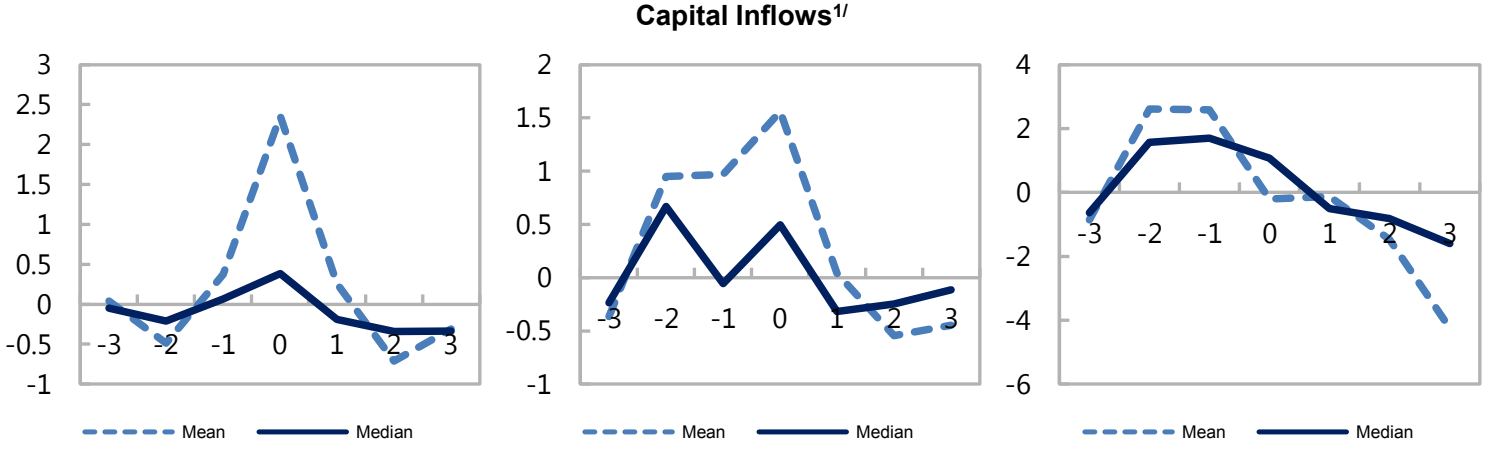

Current Account-GDP Ratio
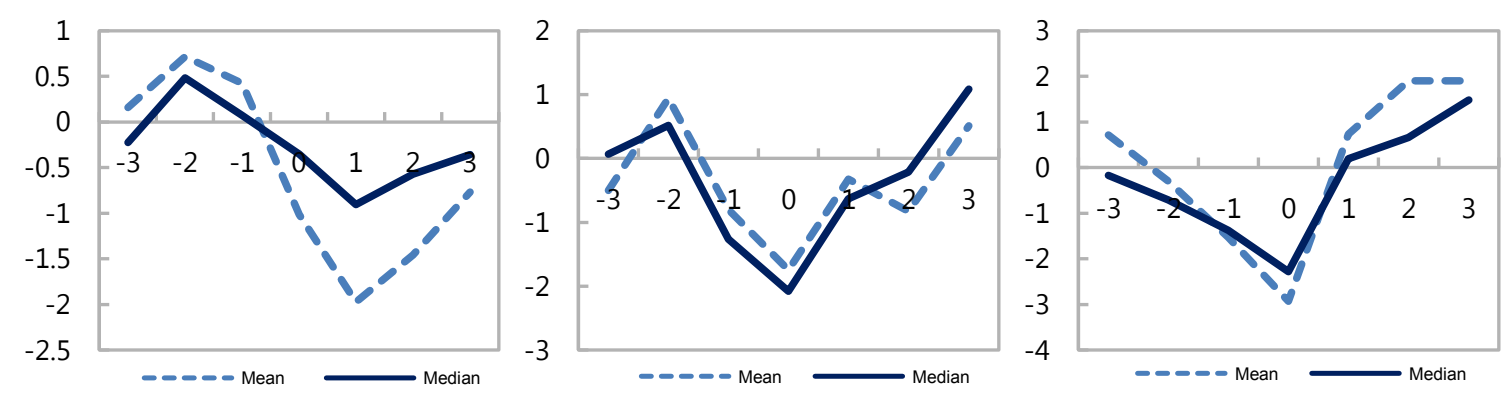

Real Money (M2)
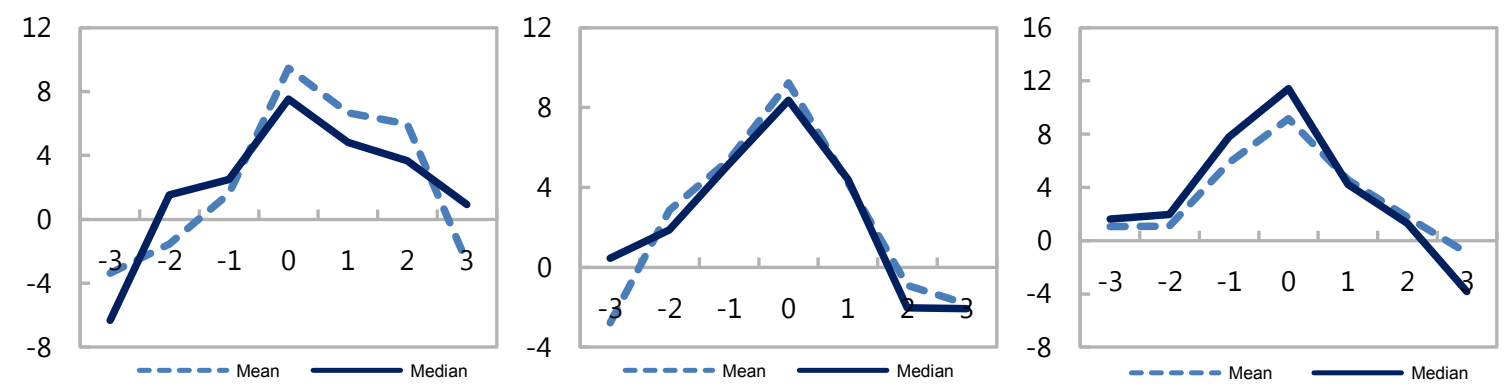
Figure 3. Credit Booms, Economic Activity and Real Exchange Rate

(Cross country means and medians of cyclical components. Based on credit booms identified when de-trending of sample is done since 1994)
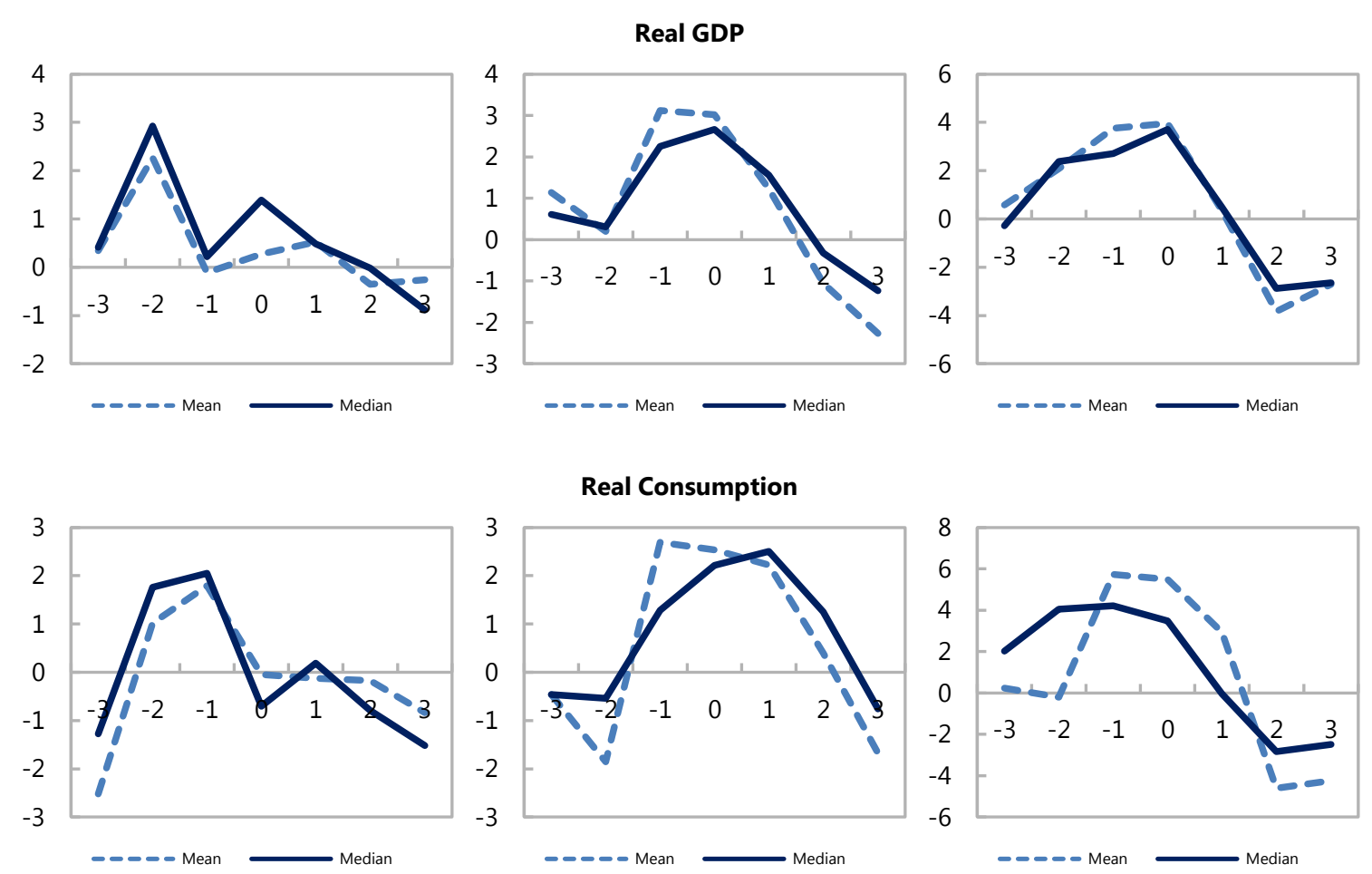

Real Exchange Rate
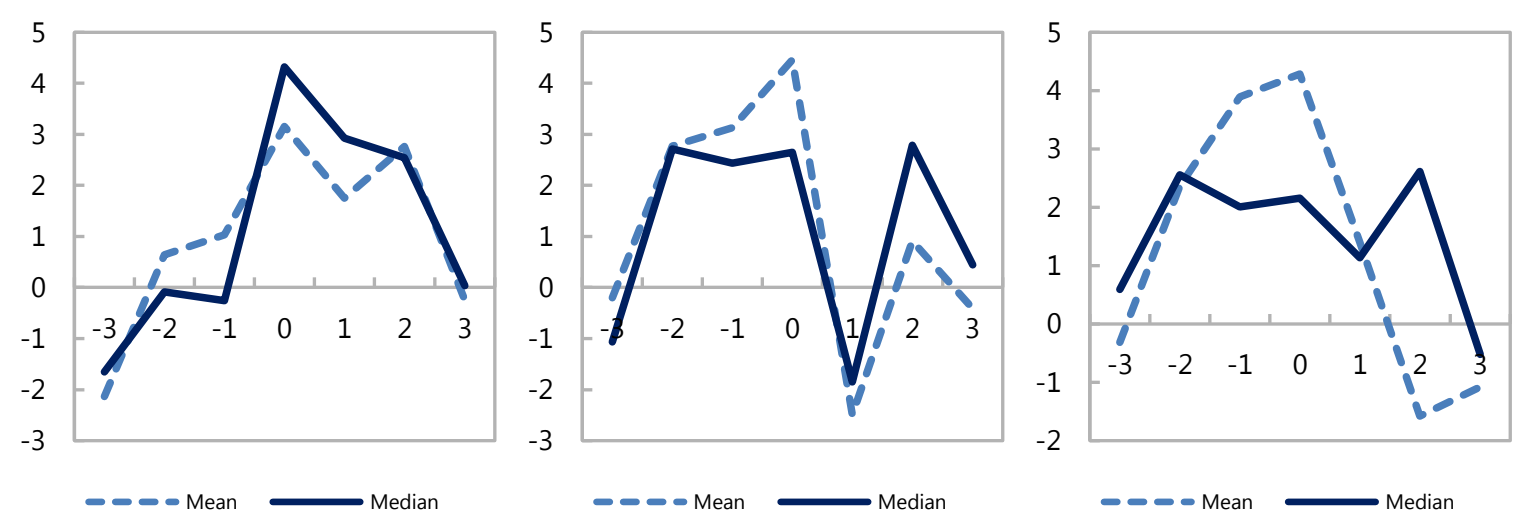

CInternational Monetary Fund. Not for Redistribution 
Figure 3 (cont'd). Credit Booms, Capital Inflows, and Current Account

(Cross country means and medians of cyclical components. Based on credit booms identified when de-trending of sample is done since 1994)
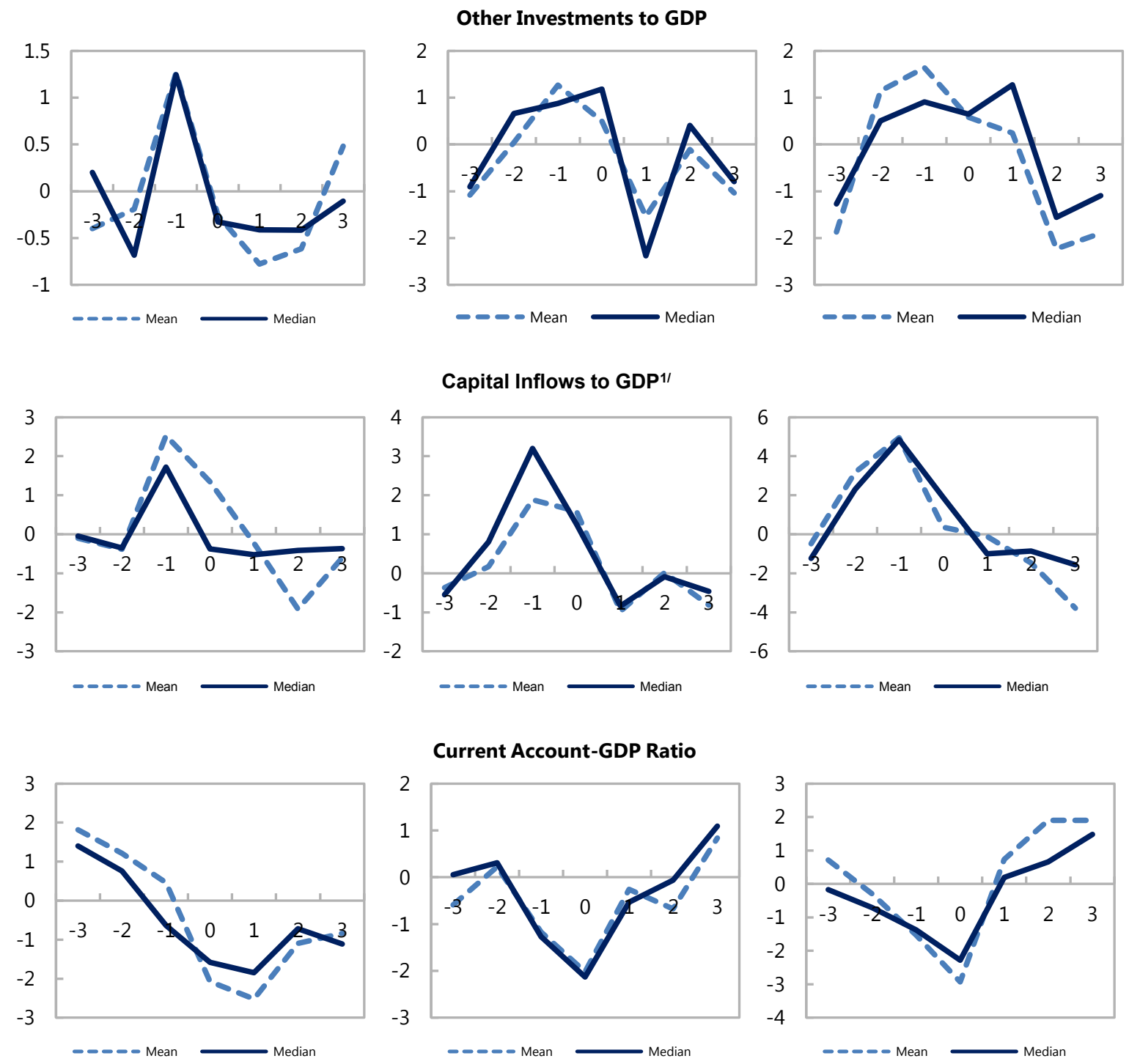

1/ Gross capital inflows include portfolio inflows, foreign direct investment, and other investments. 
Table 6. Capital Inflows Surges before the Peak of Credit Boom Episodes

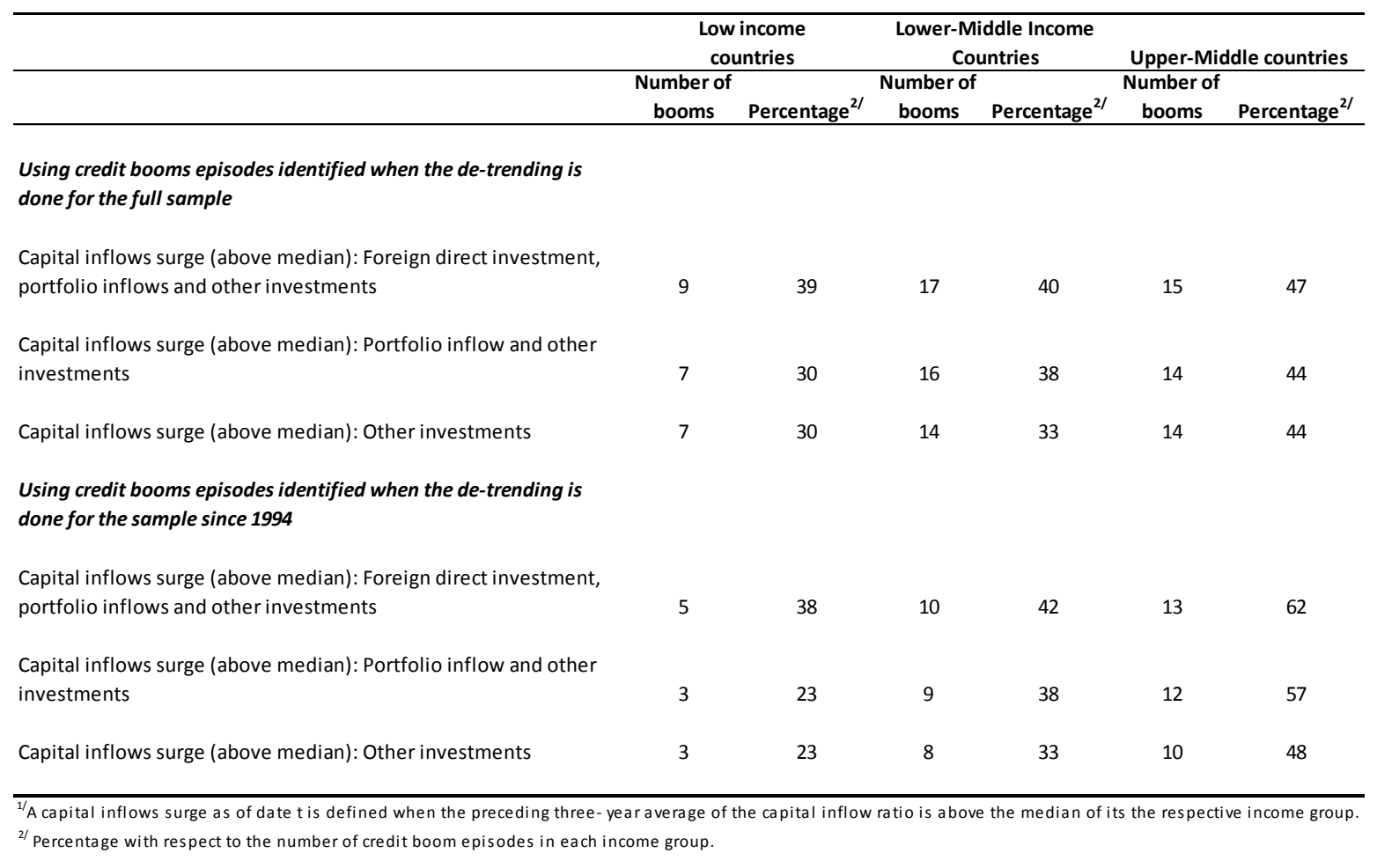

Table 7. Credit Booms and Exchange Rate Regimes

\begin{tabular}{|c|c|c|c|c|}
\hline & Low-income & $\begin{array}{l}\text { Lower-middle } \\
\text { income }\end{array}$ & $\begin{array}{l}\text { Upper-middle } \\
\text { income }\end{array}$ & All \\
\hline \multicolumn{5}{|c|}{ Credit booms identified when de-trending full sample (1960-2011) } \\
\hline Fixed and Managed ${ }^{2}$ & 45.83 & 61.90 & 72.73 & 61.62 \\
\hline Dirty Floating ${ }^{3}$ & 12.50 & 16.67 & 9.09 & 13.13 \\
\hline Floating $^{4}$ & 8.33 & 0.00 & 3.03 & 3.03 \\
\hline Other ${ }^{5}$ & 8.33 & 2.38 & 9.09 & 6.06 \\
\hline Mixed $^{6}$ & 25.00 & 19.05 & 6.06 & 16.16 \\
\hline \multicolumn{5}{|c|}{ Credit booms identified when de-trending the sample since 1994} \\
\hline Fixed and Managed ${ }^{2}$ & 61.54 & 62.50 & 66.67 & 63.79 \\
\hline Dirty Floating ${ }^{3}$ & 7.69 & 16.67 & 9.52 & 12.07 \\
\hline Floating ${ }^{4}$ & 7.69 & 0.00 & 4.76 & 3.45 \\
\hline Other $^{5}$ & 0.00 & 0.00 & 4.76 & 1.72 \\
\hline Mixed $^{6}$ & 23.08 & 20.83 & 14.29 & 18.97 \\
\hline
\end{tabular}

\footnotetext{
${ }^{1 /}$ Association between peak of credit booms and exchange rate regimes in place the preceding 3 years.

${ }^{2 /}$ Fixed and manged includes the following regimes from Reinhart-Rogoff (2010) classification: no separate legal tender, pre-announced peg or currency board arrangement, pre-announced horizantal band that is narrower than or equal to $+/-2 \%$, de facto peg, pre-announced crawling peg, pre-announced crawling band that is narrower than or equal to $+/-2 \%$, de facto crawling peg, and de facto crawling band that is narrower than or equal to $+/-2 \%$.

${ }^{3 /}$ Dirty floating includes the following regimes from Reinhart-Rogoff (2010) classification: pre-announced crawling band that is wider than or equal to $+/-2 \%$, de facto crawling band that is narrower than ot equal to $+/-2 \%$, Moving band that is narrower than or equal to $+/-2 \%$ (i.e., allows for both appreciation and depreciation over time), managed floating.

${ }^{4 /}$ Floating includes the following regime from Reinhart-Rogoff (2010) classification: Freely floating.

5/ Other includes the following regimes from Reinhart-Rogoff (2010) classification: Freely falling, dual market in which parallel market data is missing.

${ }^{6 /}$ Mixed includes cases where there was more than one exchange rate regime in the preceding 3 years of the credit boom.
}

\section{CInternational Monetary Fund. Not for Redistribution}




\section{Table 9. Credit Booms and Capital Inflows}

Dependent variable: Binary variable that takes the value of 1 when there is a credit boom

\begin{tabular}{|c|c|c|c|c|c|c|}
\hline & \multicolumn{3}{|c|}{$\begin{array}{l}\text { Measure of capital inflows: Gross other investments-to- } \\
\text { GDP }\end{array}$} & \multicolumn{3}{|c|}{$\begin{array}{c}\text { Measure of capital inflows: (Gross other investments } \\
\text { plus portfolio investment)-to-GDP }\end{array}$} \\
\hline & [1] & [2] & [3] & [4] & [5] & [6] \\
\hline \multirow[t]{2}{*}{ Capital inflows (t-1) } & -0.7590 & -0.6019 & -0.6079 & -1.1350 & -0.9061 & -1.0016 \\
\hline & 0.6622 & 0.7003 & 0.6681 & 0.6806 & 0.7049 & 0.6872 \\
\hline \multirow[t]{2}{*}{ Capital inflows (t-2) } & $0.8814^{* *}$ & $0.9377^{* *}$ & $0.8884 * *$ & $0.7429 *$ & $0.7864 *$ & $0.7586 *$ \\
\hline & 0.4468 & 0.4509 & 0.4433 & 0.4517 & 0.4549 & 0.4504 \\
\hline \multirow[t]{2}{*}{ Private sector credit/GDP (t-1) } & $1.4324 * * *$ & $1.4574 * * *$ & $1.4680 * * *$ & $1.5375 * * *$ & $1.4813 * * *$ & $1.5864 * * *$ \\
\hline & 0.2333 & 0.2402 & 0.2417 & 0.2460 & 0.2451 & 0.2570 \\
\hline \multirow[t]{2}{*}{ GDP growth rate $(\mathrm{t}-1)$} & $1.9954 * *$ & $1.9262 * *$ & $2.0464 * *$ & $1.8303 * *$ & $1.7828 * *$ & $1.9489 * *$ \\
\hline & 0.8073 & 0.8304 & 0.8205 & 0.8437 & 0.8657 & 0.8570 \\
\hline \multirow[t]{2}{*}{ Growth rate of private sector credit-to-GDP (t-1) } & $1.4998 * * *$ & $1.5038 * * *$ & $1.4981 * * *$ & $1.7591 * * *$ & $1.7747^{* * *}$ & $1.7771 * * *$ \\
\hline & 0.2230 & 0.2318 & 0.2285 & 0.2451 & 0.2550 & 0.2517 \\
\hline \multirow[t]{2}{*}{ Trade openness (t-1) } & $-0.4211 * *$ & $-0.5974 * * *$ & $-0.4519 * *$ & $-0.3655 * *$ & $-0.5044 * *$ & $-0.4046 * *$ \\
\hline & 0.1776 & 0.1887 & 0.1788 & 0.1848 & 0.1942 & 0.1867 \\
\hline \multirow[t]{2}{*}{ Growth rate of external demand $(\mathrm{t}-1)$} & 2.2453 & 2.3213 & 1.3859 & 1.9454 & 1.2696 & 1.0454 \\
\hline & 2.3041 & 2.4106 & 2.3453 & 2.4017 & 2.4937 & 2.4512 \\
\hline \multirow[t]{2}{*}{ Cylcical component of U.S. federal funds rate ( $t-3$} & $-0.0513 * *$ & $-0.0523 * *$ & $-0.0585 * * *$ & $-0.0588 * * *$ & $-0.0631 * * *$ & $-0.0660 * * *$ \\
\hline & 0.0218 & 0.0230 & 0.0223 & 0.0227 & 0.0238 & 0.0233 \\
\hline \multirow[t]{2}{*}{ Exchange rate flexibility $(\mathrm{t}-1)$} & 0.0015 & 0.0056 & -0.0008 & -0.0048 & 0.0028 & -0.0073 \\
\hline & 0.0163 & 0.0171 & 0.0163 & 0.0174 & 0.0182 & 0.0175 \\
\hline \multirow[t]{2}{*}{ Exchange rate flexibility $(t-2)$} & -0.0061 & -0.0060 & -0.0079 & -0.0039 & -0.0006 & -0.0058 \\
\hline & 0.0160 & 0.0168 & 0.0160 & 0.0172 & 0.0181 & 0.0173 \\
\hline \multirow[t]{2}{*}{ Growth rate of terms of trade $(t-1)$} & & 0.2210 & & & 0.3507 & \\
\hline & & 0.2660 & & & 0.2931 & \\
\hline \multirow[t]{2}{*}{ Inflation (t-1) } & & & -0.1148 & & & -0.1180 \\
\hline & & & 0.0734 & & & 0.0741 \\
\hline Number of observations & 2448 & 2294 & 2408 & 2246 & 2114 & 2224 \\
\hline Number of countries & 120 & 112 & 119 & 118 & 111 & 118 \\
\hline
\end{tabular}

Credit boom epsidoes are identified using the Mendoza and Terrones methodology (2012). Panel Probits estimated with random-effects. Numbers below the coefficient estimates are standard errors. ${ }^{* * *}, * *, *$ indicates that the variable is significant at the 1,5 , or 10 percent level. 
Figure 5. Credit Booms and Banking Crises

(Cross country means and medians of cyclical components)

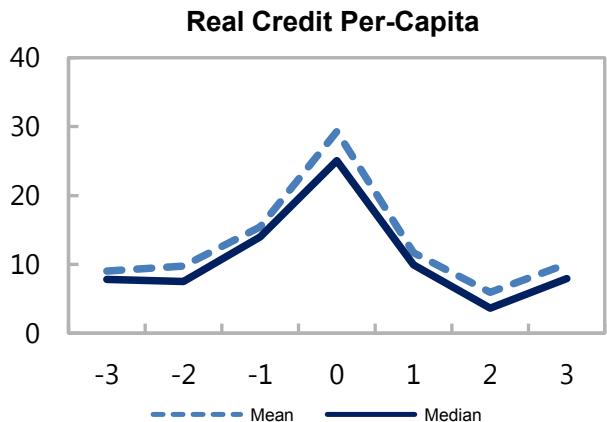

Real Credit Per-Capita

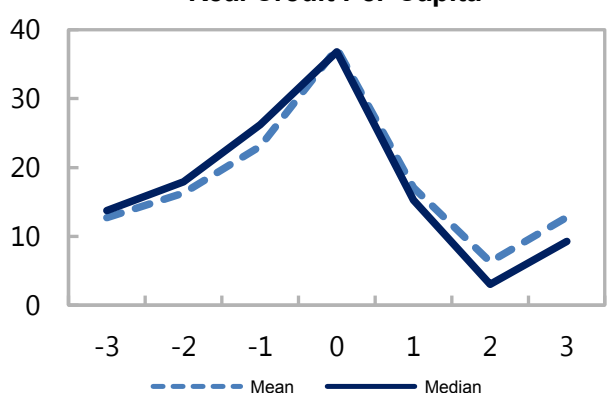

Real GDP
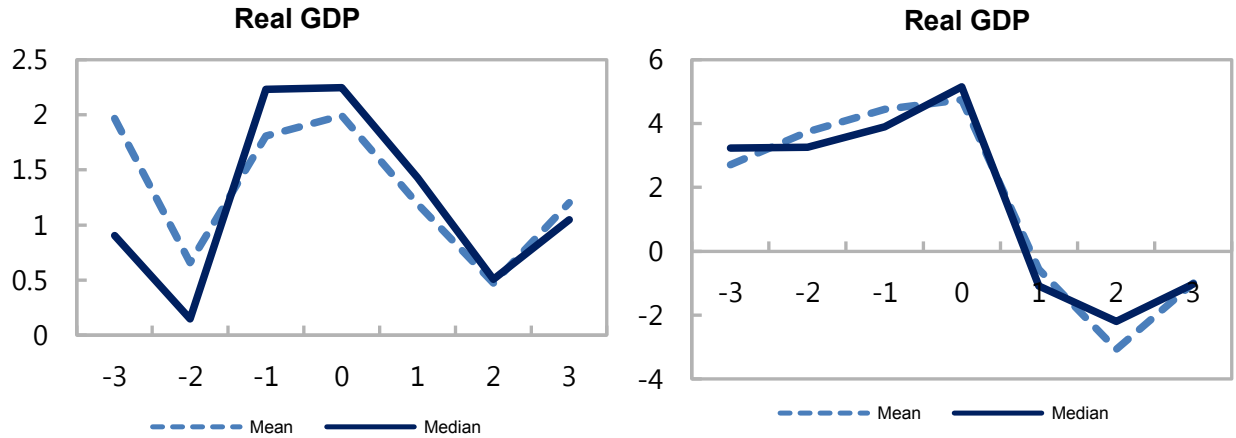

Real Consumption

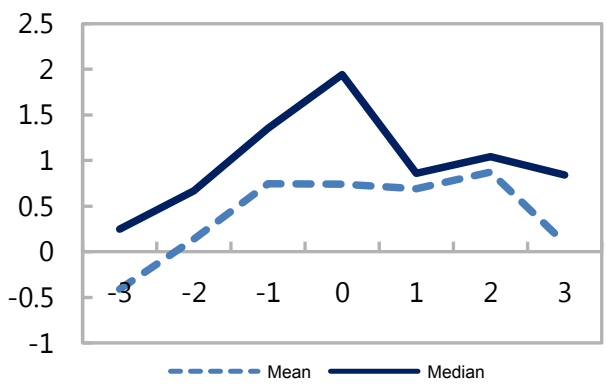

Real Consumption

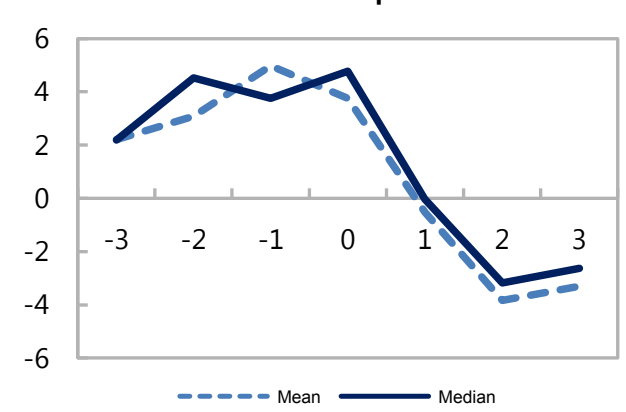

Real Investment
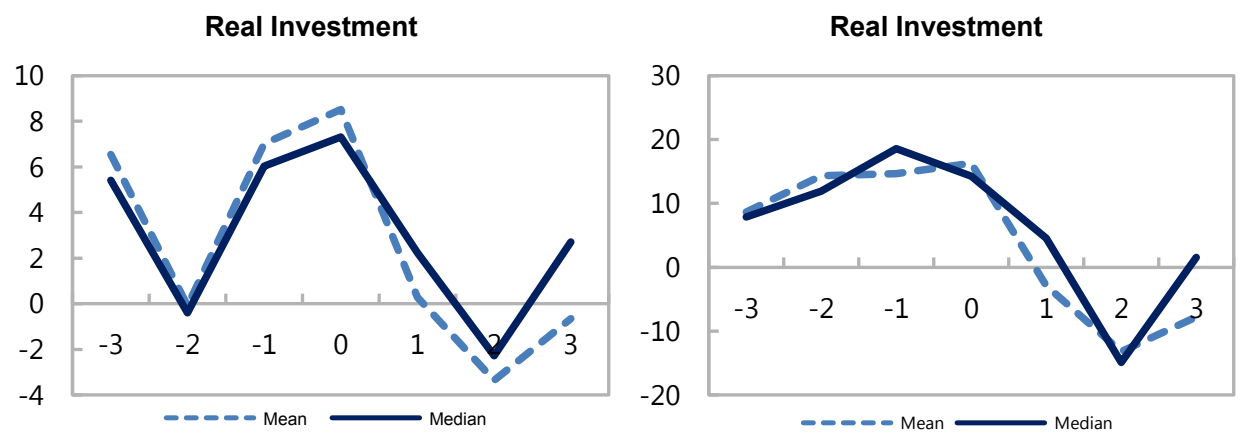

CInternational Monetary Fund. Not for Redistribution 
Figure 5 (cont'd). Credit Booms and Banking Crises

(cross country means and medians of cyclical components)

Booms not associated with banking crisis Booms associated with banking crises
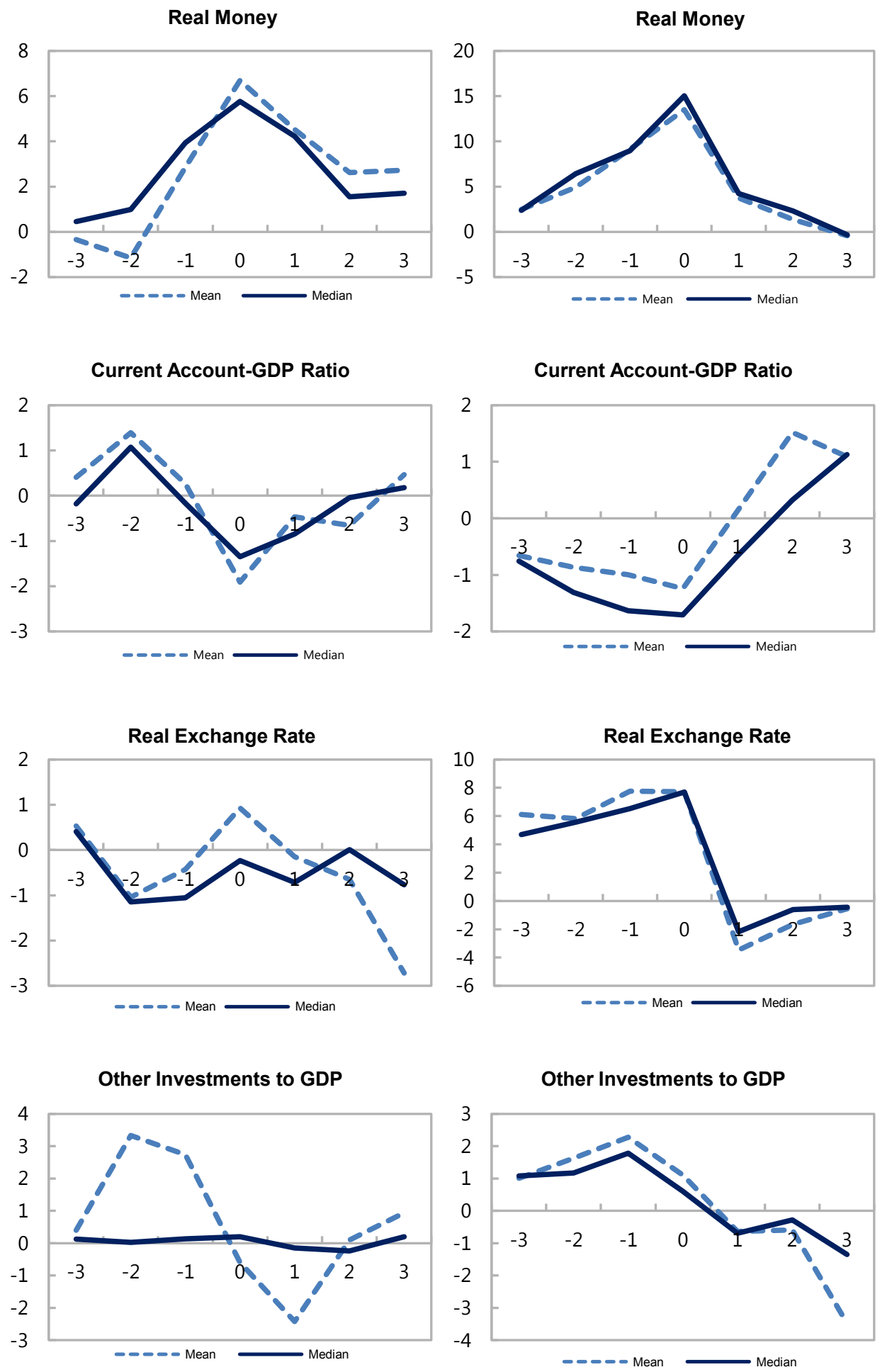

CInternational Monetary Fund. Not for Redistribution 
Table 13. Benchmarking Exercise: Financial Possibility Frontier

\begin{tabular}{|c|c|c|}
\hline & {$[1]$} & [2] \\
\hline \multirow[t]{2}{*}{ Log GDP per capita } & $0.4473 * * *$ & $0.4623 * * *$ \\
\hline & 0.0650 & 0.0740 \\
\hline \multirow[t]{2}{*}{ Log GDP per capita ${ }^{2}$} & $0.0181 * * *$ & $0.0188 * * *$ \\
\hline & 0.0028 & 0.0032 \\
\hline \multirow[t]{2}{*}{ Log population } & $0.0961 * * *$ & $0.0958 * * *$ \\
\hline & 0.0088 & 0.0097 \\
\hline \multirow[t]{2}{*}{ Log population density } & 0.0147 & $0.0407^{* * *}$ \\
\hline & 0.0112 & 0.0128 \\
\hline \multirow[t]{2}{*}{ Log age dependence ratio } & $-1.3106 * * *$ & $-1.3548 * * *$ \\
\hline & 0.0821 & 0.0868 \\
\hline \multirow[t]{2}{*}{ Dummy off-shore financial center } & $0.5488^{* * *}$ & $0.6163 * * *$ \\
\hline & 0.0481 & 0.0522 \\
\hline \multirow[t]{2}{*}{ Dummy fuel exporters } & $0.3653^{* * *}$ & $0.5233 * * *$ \\
\hline & 0.0657 & 0.0737 \\
\hline \multirow[t]{2}{*}{ Dummy transition countries } & $-0.5979 * * *$ & $-0.6516^{* * *}$ \\
\hline & 0.0588 & 0.0599 \\
\hline \multirow[t]{2}{*}{ Inflation } & & $-0.0002 * * *$ \\
\hline & & 0.0001 \\
\hline \multirow[t]{2}{*}{ Exchange rate regime indicator } & & 0.0083 \\
\hline & & 0.0053 \\
\hline \multirow[t]{2}{*}{ GDP growth } & & $-0.0166 * * *$ \\
\hline & & 0.0037 \\
\hline Time dummies & YES & YES \\
\hline Number of observations & 3864 & 3365 \\
\hline R_Squared & 0.79 & 0.80 \\
\hline
\end{tabular}

Regression estimated with pooled OLS. Numbers below the coefficient estimates

are standard errors. ${ }^{* * *},{ }^{* *}, *$ indicates that the variable is significant at the 1,5, or 10 percent level. 


\section{Appendix I. Sample of Countries}

\begin{tabular}{|c|c|c|c|}
\hline Low-income $^{1}$ & Lower-middle-income $2^{2}$ & Upper-middle-income $3^{3}$ & High-income $4^{4}$ \\
\hline Bangladesh & Albania & Algeria & Bahrain \\
\hline Benin & Armenia & Angola & Barbados \\
\hline Burkina Faso & Belize & Antigua \& Barbuda & Brunei Darussalam \\
\hline Burundi & Bhutan & Argentina & Croatia \\
\hline C.A.R. & Bolivia & Azerbaijan & Equatorial Guinea \\
\hline Cambodia & Cameroon & Belarus & Hong Kong \\
\hline Chad & Cape Verde & Botswana & Hungary \\
\hline Comoros & Congo, Rep. & Brazil & Kuwait \\
\hline Eritrea & Côte d'Ivoire & Bulgaria & Oman \\
\hline Ethiopia & Djibouti & Chile & Poland \\
\hline Gambia, The & Egypt & China & Qatar \\
\hline Guinea & El Salvador & Colombia & Saudi Arabia \\
\hline Guinea-Bissau & Fiji & Costa Rica & St. Kitts and Nevis \\
\hline Haiti & Georgia & Dominica & Trinidad and Tobago \\
\hline Kenya & Ghana & Dominican Rep. & U.A.E. \\
\hline Kyrgyz Republic & Guatemala & Ecuador & \\
\hline Liberia & Guyana & Gabon & \\
\hline Madagascar & Honduras & Grenada & \\
\hline Malawi & India & Jamaica & \\
\hline Mali & Indonesia & Jordan & \\
\hline Mauritania & Laos & Kazakhstan & \\
\hline Mozambique & Lesotho & Latvia & \\
\hline Myanmar & Moldova & Libya & \\
\hline Nepal & Mongolia & Lithuania & \\
\hline Niger & Morocco & Macedonia, FYR & \\
\hline Rwanda & Nicaragua & Malaysia & \\
\hline Sierra Leone & Nigeria & Maldives & \\
\hline Tajikistan & Pakistan & Mauritius & \\
\hline Tanzania & Papua New Guinea & Mexico & \\
\hline Togo & Paraguay & Namibia & \\
\hline Uganda & Philippines & Peru & \\
\hline \multirow[t]{14}{*}{ Zimbabwe } & Samoa & Romania & \\
\hline & São Tomé and Príncipe & Russia & \\
\hline & Senegal & Seychelles & \\
\hline & Solomon Islands & South Africa & \\
\hline & Sri Lanka & St. Lucia & \\
\hline & Sudan & St. Vincent \& Grenadines & \\
\hline & Swaziland & Suriname & \\
\hline & Syria & Thailand & \\
\hline & Tonga & Tunisia & \\
\hline & Ukraine & Turkey & \\
\hline & Vanuatu & Uruguay & \\
\hline & Vietnam & Venezuela & \\
\hline & Yemen & & \\
\hline & Zambia & & \\
\hline
\end{tabular}

Source: World Bank Classification

${ }^{1}$ Low-income economies (GNI per capita of $\$ 1,025$ or less).

${ }^{2}$ Lower-middle-income economies (GNI per capita of $\$ 1,026$ to $\$ 4,035$ ).

${ }^{3}$ Upper-middle-income economies (GNI per capita of $\$ 4,036$ to $\$ 12,475$ ).

${ }^{4} \mathrm{High}$-income economies (GNI per capita of $\$ 12,475$ or more). 


\section{Appendix II. Description and Definition of Main Variables}

\begin{tabular}{|c|c|c|}
\hline Variable & Variable Definition & Source \\
\hline \multicolumn{3}{|l|}{ A Macroeconomic and financial data } \\
\hline Credit to the non-financial private sector & $\begin{array}{l}\text { Sum of claims on the private sector by } \\
\text { deposit money banks (IFS line } 22 \mathrm{~d} \text { ) plus } \\
\text { whenever available for the entire sample } \\
\text { period by other financial institutions } \\
\text { (IFS line } 42 \mathrm{~d} \text { and sub-items). }\end{array}$ & IFS and staff reports. \\
\hline M2 & Sum of money and quasimoney & IFS. \\
\hline Consumer price index & Consumer price index (both average and end-of-period). & IFS and WEO. \\
\hline Nominal GDP & GDP in current prices, local currency. & WDI \\
\hline Population & Population & WDI \\
\hline Real GDP & Real GDP per-capita, international prices & PWT 7.1 \\
\hline Private Consumption & Real private consumption per-capita, in international prices & PWT 7.1 \\
\hline Government Consumption & Real government consumption per-capita, in international prices & PWT 7.1 \\
\hline Investment & Real investment per-capitam, in international prices & PWT 7.1 \\
\hline Non-tradable GDP & $\begin{array}{l}\text { Sum of the value added in services plus the value added in } \\
\text { industry minus infrastructure. }\end{array}$ & WDI \\
\hline Current account balance & Current account as percent of GDP & WDI \\
\hline Real exchange rate & Real effective exchange rate, index & INS (IMF) \\
\hline Capital inflows & Other investments liabilities, portfolio liabilities & IFS \\
\hline Terms of trade & Terms of trade & WEO \\
\hline External Demand & GDP growth rate of trading partners weighted by country's exports & WEO \\
\hline International interest rate & U.S. federal funds rate & IFS \\
\hline \multicolumn{3}{|l|}{ B. Crises \& definitions } \\
\hline Banking Crises & $\begin{array}{l}\text { A country is considered to have experienced a systemic banking crisis } \\
\text { if its banking system experienced significant signs of financial stress } \\
\text { (indicated by significant bank runs, losses, and bank liquidations) and also, } \\
\text { if significant policy interventions can be observed in response to the losses } \\
\text { in the banking system. Policy interventions are considered to be significant } \\
\text { if the following forms of interventions have been used: significant guarantees } \\
\text { are put in place, extensive liquidity support ( } 5 \text { percent of deposits and } \\
\text { liabilities to nonresidents), bank restructuring costs (at least } 3 \text { percent of } \\
\text { GDP), and significant bank nationalizations took place. }\end{array}$ & Laeven and Valencia (2012). \\
\hline \multicolumn{3}{|l|}{ C. Other variables } \\
\hline Financial reform index & $\begin{array}{l}\text { The index captures changes in seven financial policy dimensions: } \\
\text { (1) credit controls and reserve requirements; (2) Interest rate controls; } \\
\text { (3) Entry barriers; (4) State ownership in the banking sector; } \\
\text { (5) Capital account restrictions; (6) Prudential regulations and } \\
\text { supervision of the banking sector; and (7) Securities market policy. } \\
\text { The index is just the sum of these seven dimensions (each of which } \\
\text { can take values between } 0 \text { and } 3 \text { ) and takes values between } \\
0 \text { (the lowest) and } 21 \text { (the highest). }\end{array}$ & Abiad, Detragiache, and Tressel (2008) \\
\hline Financial Openness index & $\begin{array}{l}\text { Index measuring a country's degree of capital account openness and } \\
\text { is based on the binary dummy variables that codify the tabulation of } \\
\text { restrictions on cross-border financial transactions reported in the IMF's } \\
\text { Annual Report on Exchange Arrangements and Exchange Restrictions. }\end{array}$ & Chinn and Ito (2006). Lats update 2011. \\
\hline
\end{tabular}




\section{Appendix III. Boom Episodes List}

\begin{tabular}{|c|c|c|c|c|c|c|c|}
\hline \multicolumn{2}{|c|}{ Low-income } & \multicolumn{2}{|c|}{ Lower-middle-income } & \multicolumn{2}{|c|}{ Upper-middle-income } & \multicolumn{2}{|c|}{ High-income } \\
\hline & Start Peak End & & Start Peak End & & Start Peak End & & Start Peak End \\
\hline Bangladesh & 197619771979 & Belize & 199019921993 & Antigua \& Barbuda & 200620082010 & Bahrain & 198219841987 \\
\hline Bangladesh & 198319841990 & Bhutan & 199119941995 & Azerbaijan & 199719982000 & Bahrain & 200620082009 \\
\hline Burkina Faso & 197419761979 & Bhutan & 199619971998 & Botswana & 199019921994 & Barbados & 196919701973 \\
\hline Burkina Faso & 198619901992 & Bolivia & 197519781982 & Brazil & 198219851987 & Croatia & 199619981999 \\
\hline Burundi & 197819811983 & Cameroon & 198619911992 & Chile & 197719801984 & Equatorial Guinea & 198619911992 \\
\hline Central African Rep. & 198519901991 & Cape Verde & 199819992001 & Colombia & 199319971999 & Hong Kong & 199419971998 \\
\hline Cambodia & 199519972000 & Congo, Rep. & 199719992001 & Costa Rica & 197619791981 & Hungary & 198619871991 \\
\hline Cambodia & 200620082010 & Côte d'Ivoire & 196319641965 & Dominica & 197719781979 & Kuwait & 199319971999 \\
\hline Chad & 198419861988 & Côte d'Ivoire & 197419771979 & Dominican Rep. & 199720012003 & Oman & 199719982001 \\
\hline Eritrea & 199619981999 & Djibouti & 199519981999 & Ecuador & 199319971999 & Qatar & 199119931995 \\
\hline Ethiopia & 199519962001 & Egypt & 198019811988 & Gabon & 198819911992 & St. Kitts and Nevis & 198819891990 \\
\hline Gambia, The & 197719851986 & El Salvador & 197619851986 & Gabon & 200620072008 & Trinidad \& Tobago & 197719781985 \\
\hline Guinea-Bissau & 199720002001 & Fiji & 200420062009 & Grenada & 197719781980 & Trinidad \& Tobago & 200520072009 \\
\hline Haiti & 199920022003 & Georgia & 200520072009 & Grenada & 198619891991 & U.A.E. & 200520082009 \\
\hline Madagascar & 198919931994 & Ghana & 198419861989 & Jamaica & 198719891991 & & \\
\hline Malawi & 198919921994 & Guatemala & 197819841985 & Malaysia & 199519972000 & & \\
\hline Myanmar & 197719781985 & Guatemala & 199419952000 & Maldives & 200520082009 & & \\
\hline Nepal & 197019711975 & Honduras & 198519871989 & Mexico & 197719811982 & & \\
\hline Nepal & 197819811982 & Honduras & 200620072009 & Mexico & 199119941996 & & \\
\hline Nepal & 199419952001 & India & 198819891990 & Peru & 198119871987 & & \\
\hline Tajikistan & 200420072008 & India & 200420072008 & Russia & 200420082009 & & \\
\hline Tanzania & 198919911994 & Indonesia & 198919971998 & South Africa & 200520072008 & & \\
\hline \multirow[t]{20}{*}{ Togo } & 197519781981 & Lesotho & 199319972002 & St. Lucia & 198819891991 & & \\
\hline & & Moldova & 199519961998 & St. Vincent \& Grenadines & 197719781982 & & \\
\hline & & Nicaragua & 199719992000 & Thailand & 199219971999 & & \\
\hline & & Nigeria & 200620082010 & Tunisia & 198919891991 & & \\
\hline & & Pakistan & 198419861989 & Tunisia & 200020012005 & & \\
\hline & & Pakistan & 200320072009 & Turkey & 197319761978 & & \\
\hline & & Philippines & 197719831984 & Turkey & 199519971999 & & \\
\hline & & Philippines & 199419972000 & Uruguay & 197819821983 & & \\
\hline & & Samoa & 200520062008 & Uruguay & 199720022003 & & \\
\hline & & São Tomé and Príncipe & 200320052007 & Venezuela & 200520072009 & & \\
\hline & & Senegal & 197819811983 & & & & \\
\hline & & Senegal & 198819931993 & & & & \\
\hline & & Solomon Islands & 198719891989 & & & & \\
\hline & & Sudan & 198519871989 & & & & \\
\hline & & Sudan & 200220052008 & & & & \\
\hline & & Swaziland & 199019911995 & & & & \\
\hline & & Syria & 196219661967 & & & & \\
\hline & & Syria & 197819831985 & & & & \\
\hline & & Ukraine & 200520082009 & & & & \\
\hline & & Vanuatu & 200820092011 & & & & \\
\hline
\end{tabular}




\section{Appendix IV. Robustness using the Mendoza and Terrones' methodology and application of the Tornell and Westermann's approach}

This Appendix compares results presented in Section III.A to the results stemming from variations in the employed methodology: (a) using a more stringent threshold factor of 2 instead of 1.65, and (b) use of credit-to-GDP ratio instead of real credit per capita. In addition, this appendix implements Tornell and Westermann (2002) approach to identify credit booms.

a. Using a more stringent threshold factor. Using a threshold factor of 2 instead of 1.65 in the methodology put forward by Mendoza and Terrones (2012) does not change the qualitative results show in Table 1.

\begin{tabular}{|c|c|c|c|c|c|c|}
\hline & \multicolumn{3}{|c|}{ Boom parameter $=1.65^{1 /}$} & \multicolumn{3}{|c|}{ Boom parameter $=2.00^{2 /}$} \\
\hline & Low Income & $\begin{array}{c}\text { Lower } \\
\text { Middle } \\
\text { Income }\end{array}$ & $\begin{array}{c}\text { Upper } \\
\text { Middle } \\
\text { Income }\end{array}$ & Low Income & $\begin{array}{l}\text { Lower } \\
\text { Middle } \\
\text { Income }\end{array}$ & $\begin{array}{c}\text { Upper } \\
\text { Middle } \\
\text { Income }\end{array}$ \\
\hline De-trending full sample (1960-2011) & 23 & 42 & 32 & 9 & 21 & 14 \\
\hline For episodes in the 1990 s & 9 & 15 & 9 & 3 & 8 & 5 \\
\hline For episodes since 2000 & 4 & 11 & 9 & 2 & 3 & 4 \\
\hline De-trending sample since 1994 & 13 & 24 & 21 & 4 & 9 & 6 \\
\hline For episodes since 2000 & 7 & 13 & 13 & 2 & 4 & 4 \\
\hline
\end{tabular}

b. Use of credit-to-GDP ratio. Because of the positive relationship between financial development and GDP growth, bank lending follows a positive trend, even when measured relative to GDP. Therefore, as notedby Barajas et al. (2009), credit booms need to be isolated as definite events separate from normal increments in the volume of credit (pro-cyclicality of bank lending). In this vein, we implement the Mendoza and Terrones methodology (2012) using the credit-to-GDP ratio instead of real credit per capita.

A total of 104 credit boom episodes are identified for 135 developing countries. About 60 percent of the credit booms identified using real credit per capita are also identified when using the credit-to-GDP ratio. 
Most credit boom episodes occur in the group of lower-middle income and upper-middle income countries ( 36 and 38 percent respectively). A lower proportion of credit boom episodes occurs low-income countries ( 22 percent). In addition, between 60 and 68 percent of boom episodes across income groups have occurred in the last 20 years. Regarding the duration of the boom episodes, the results based on medians indicate that the duration of booms is 5 years. However, the duration of booms isone year lower for recent episodes. ${ }^{33}$ For the last 3 (5) yearsbetween 30 (22) and 50 (28) percent of credit boom episodes were associated with a growth rate of real credit per capita of at least 5 percent.

\begin{tabular}{|c|c|c|c|c|c|c|}
\hline & \multicolumn{3}{|c|}{ Variable: real credit per capita } & \multicolumn{3}{|c|}{ Variable: credit-to-GDP ratio } \\
\hline & Low Income & $\begin{array}{l}\text { Lower } \\
\text { Middle } \\
\text { Income }\end{array}$ & $\begin{array}{l}\text { Upper } \\
\text { Middle } \\
\text { Income }\end{array}$ & Low Income & $\begin{array}{l}\text { Lower } \\
\text { Middle } \\
\text { Income }\end{array}$ & $\begin{array}{c}\text { Upper } \\
\text { Middle } \\
\text { Income }\end{array}$ \\
\hline De-trending full sample (1960-2011) & 23 & 42 & 32 & 23 & 37 & 40 \\
\hline For episodes in the 1990 s & 9 & 15 & 9 & 8 & 14 & 18 \\
\hline For episodes since 2000 & 4 & 11 & 9 & 6 & 8 & 9 \\
\hline De-trending sample since 1994 & 13 & 24 & 21 & 15 & 20 & 23 \\
\hline For episodes since 2000 & 7 & 13 & 13 & 10 & 7 & 12 \\
\hline
\end{tabular}

\section{c. Applying a cumulative credit growth analysis à la Tornell and Westermann (2002).}

According to this approach, acredit boom takes place when the cumulative growth in real credit over the past two years has been at least 20 percent. To avoid potential one-off events across time and countries, we make the following modification. A credit boom episode is defined when the condition used by Tornell and Westermann (2002) is satisfied in, at least, three consecutive years.

Over 700 boom episodes are identified in our sample ( 70 percent of these episodes occurred in the last two decades). ${ }^{34}$ Between 40 and about 60 percent of booms identified using the methodology of Mendoza and Terrones (2012) are also identified under this methodology (see text table).

\footnotetext{
${ }^{33}$ Using an alternative (larger) start and end threshold, lower and upper-middle income groups show a similar duration period of 5 years. Low income countries would still show duration of 4 years.

${ }^{34}$ The number of episodes decline to around 400 when a threshold of 30 percent is used instead. In this case, above 75 percent of the boom episodes occurred in the last two decades.
} 


\begin{tabular}{lc|c}
\hline & $\begin{array}{c}\text { Cummulative credit } \\
\text { growth of 20 percent } \\
\text { over the past 2 years }\end{array}$ & $\begin{array}{c}\text { Cummulative credit } \\
\text { growth of 30 percent } \\
\text { over the past 2 years }\end{array}$ \\
\hline $\begin{array}{l}\text { Overlapping with credit booms } \\
\text { identified with real credit per } \\
\text { capita [Mendoza and Terrones } \\
\text { methodology (\%)] }\end{array}$ & 56 & 38 \\
\hline
\end{tabular}

In addition, this methodology also allows us to identify boom episodes that cannot be captured under any other de-trending methodology. This is the case when countries are experiencing sustained real credit growth almost following a linear trend. For example, Vietnam has experienced a sustained growth in real credit between 1999 and 2010, which is not identified under a de-trending methodology. Credit growth has already decelerated but there have been some signs of banking sector distress, in particular in small banks. In this context, cases like Vietnam are important to identify given that they could give rise to or amplify banking sector vulnerabilities. In our sample, as of 2011, we identify 11 potential ongoing boom episodes in low and lower-middle income countries and 2 in upper-middle income countries. ${ }^{35}$

As in the case of the MT methodology, we also apply this modified WT methodology to the credit to GDP ratio. ${ }^{36}$ Around 650 boom episodes are identified $(75$ percent of them in the last two decades). Between 40 and 50 percent of booms identified using the methodology of Mendoza and Terrones ( 2012) are also identified under this methodology. In addition, the same ongoing boom episodes mentioned above for low- and lower-middle income countries are also identified with some additions.

\begin{tabular}{lc|c}
\hline & $\begin{array}{c}\text { Cummulative credit } \\
\text { growth of 10 percent } \\
\text { over the past 2 years }\end{array}$ & $\begin{array}{c}\text { Cummulative credit } \\
\text { growth of 20 percent } \\
\text { over the past 2 years }\end{array}$ \\
\hline $\begin{array}{l}\text { Overlapping with credit booms } \\
\text { identified with credit-to-GDP } \\
\text { [Mendoza and Terrones } \\
\text { methodology (\%)] }\end{array}$ & 53 & 37 \\
\hline
\end{tabular}

\footnotetext{
${ }^{35}$ Bangladesh (2008-11), Bhutan (2001-11), Cambodia (2003-11), Chad (2008-11), Republic of Congo (2008-11), Guinea-Bissau (2005-11), Lesotho (2005-11), Liberia (2005-11), Malawi (2003-11), Niger (200311), Uganda (2006-11). Eight of these episodes are still in place if a threshold of 30 percent is used.

${ }^{36}$ The threshold is 10 percent. A robustness analysis was done with a threshold of 20 percent.
} 


\section{Appendix V. Credit Booms: Significance of Event Window Coefficients}

\begin{tabular}{|c|c|c|c|c|c|c|c|c|c|}
\hline & \multicolumn{3}{|c|}{ Low-Income Countries } & \multicolumn{3}{|c|}{ Lower-Middle Income Countries } & \multicolumn{3}{|c|}{ Upper-Middle Income Countries } \\
\hline & peak-1 & peak & peak+1 & peak-1 & peak & peak +1 & peak-1 & peak & peak +1 \\
\hline Real GDP & 0.011 & 0.013 & 0.006 & $0.020 * * *$ & $0.015 *$ & 0.005 & $0.036 * * *$ & $0.046 * * *$ & 0.014 \\
\hline Real Credit & $0.163 * * *$ & $0.338 * * *$ & $0.124 * * *$ & $0.154 * * *$ & $0.300 * * *$ & $0.109 * * *$ & $0.230 * * *$ & $0.321 * * *$ & $0.114 * * *$ \\
\hline Real Consumption & $0.023 * *$ & 0.000 & 0.006 & 0.007 & 0.003 & 0.017 & $0.042 * * *$ & $0.042 * * *$ & 0.015 \\
\hline Real Investment & 0.039 & $0.078 * *$ & 0.038 & $0.084 * * *$ & $0.104 * * *$ & -0.017 & $0.099 * * *$ & $0.118 * * *$ & 0.022 \\
\hline Real Money & 0.016 & $0.094 * * *$ & $0.067 *$ & $0.054 * * *$ & $0.092 * * *$ & $0.042 * *$ & $0.058 * *$ & $0.092 * * *$ & $0.046 * *$ \\
\hline Current account ratio & 0.421 & -1.010 & $-1.973 * *$ & -1.002 & $-1.514 * *$ & -0.412 & -0.511 & $-1.716 * *$ & 0.829 \\
\hline Real Exchange Rate & -0.026 & 0.004 & 0.000 & $0.035 * *$ & $0.036 * *$ & -0.024 & $0.039 *$ & $0.046 * *$ & -0.012 \\
\hline External Demand & $0.007 *$ & 0.004 & -0.002 & 0.004 & 0.005 & 0.002 & $0.009 * * *$ & $0.009 * *$ & -0.002 \\
\hline
\end{tabular}

The coeffcients are obtained by regressing each macroeoncomic aggregate on a constant. The symbols *, **, and ${ }^{* * *}$ indicate statistical significance at the $10 \%, 5 \%$, and $1 \%$ level respectively. 


\section{Appendix VI. Robustness-Credit Booms and Net Capital Inflows}

\begin{tabular}{|c|c|c|c|c|c|c|}
\hline & \multicolumn{3}{|c|}{$\begin{array}{c}\text { Measure of net capital inflows: Net other } \\
\text { investments-to-GDP }\end{array}$} & \multicolumn{3}{|c|}{$\begin{array}{l}\text { Measure of net capital inflows: (net other } \\
\text { investments plus net portfolio investment)-to-GDP }\end{array}$} \\
\hline & [1] & {$[2]$} & [3] & [4] & [5] & [6] \\
\hline \multirow[t]{2}{*}{ Net capital inflows (t-1) } & -0.3787 & -0.3857 & -0.3150 & -0.6606 & -0.4007 & -0.5927 \\
\hline & 0.6431 & 0.7021 & 0.6539 & 0.7890 & 0.8367 & 0.8083 \\
\hline \multirow[t]{2}{*}{ Net capital inflows (t-2) } & $2.9936 * * *$ & $1.4255^{* * *}$ & $1.4574 * * *$ & $2.7726 * * *$ & $2.8147 * * *$ & $2.8317^{* * *}$ \\
\hline & 0.6951 & 0.2404 & 0.2435 & 0.7473 & 0.7875 & 0.7583 \\
\hline \multirow[t]{2}{*}{ Private sector credit/GDP (t-1) } & $1.4144^{* * *}$ & $1.4255 * * *$ & $1.6270^{* * *}$ & $1.4501 * * *$ & $1.3970 * * *$ & $1.5081 * * *$ \\
\hline & 0.2345 & 0.2404 & 0.2435 & 0.2427 & 0.2424 & 0.2541 \\
\hline \multirow[t]{2}{*}{ GDP growth rate (t-1) } & $1.6701 * *$ & $1.5608 *$ & $1.7060^{* *}$ & $1.5696 *$ & $1.5012 *$ & $1.6703 *$ \\
\hline & 0.8239 & 0.8494 & 0.8376 & 0.8585 & 0.8821 & 0.8728 \\
\hline \multirow[t]{2}{*}{ Growth rate of private sector credit-to-GDP (t-1) } & $1.6266 * * *$ & $1.6314^{* * *}$ & $1.6270^{* * *}$ & $1.7547^{* * *}$ & $1.7606 * * *$ & $1.7798^{* * *}$ \\
\hline & 0.2370 & 0.2470 & 0.2435 & 0.2542 & 0.2651 & 0.2624 \\
\hline \multirow[t]{2}{*}{ Trade openness ( $t-1$ ) } & $-0.3376 *$ & $-0.5118 * * *$ & $-0.3701 * *$ & -0.2277 & $-0.3542 *$ & -0.2681 \\
\hline & 0.1813 & 0.1925 & 0.1825 & 0.1882 & 0.1984 & 0.1902 \\
\hline \multirow[t]{2}{*}{ Growth rate of external demand ( $\mathrm{t}-1)$} & 2.8356 & 2.8790 & 2.0248 & 2.1635 & 1.6029 & 1.3041 \\
\hline & 2.3454 & 2.4585 & 2.3883 & 2.4358 & 2.5357 & 2.4873 \\
\hline \multirow[t]{2}{*}{ Cylcical component of U.S. federal funds rate $(t-3)$} & $-0.0562 * * *$ & $-0.0594 * * *$ & $-0.0638^{* * *}$ & $-0.0588 * * *$ & $-0.0639 * * *$ & $-0.0665 * * *$ \\
\hline & 0.0221 & 0.0233 & 0.0226 & 0.0231 & 0.0243 & 0.0237 \\
\hline \multirow[t]{2}{*}{ Exchange rate flexibility (t-1) } & 0.0022 & 0.0063 & -0.0003 & -0.0007 & 0.0071 & -0.0037 \\
\hline & 0.0167 & 0.0175 & 0.0167 & 0.0181 & 0.0191 & 0.0182 \\
\hline \multirow[t]{2}{*}{ Exchange rate flexibility (t-2) } & -0.0074 & -0.0067 & -0.0092 & -0.0142 & -0.0120 & -0.0164 \\
\hline & 0.0164 & 0.0172 & 0.0164 & 0.0180 & 0.0190 & 0.0181 \\
\hline \multirow[t]{2}{*}{ Growth rate of terms of trade $(\mathrm{t}-1)$} & & 0.2055 & & & 0.4339 & \\
\hline & & 0.2768 & & & 0.3081 & \\
\hline \multirow[t]{2}{*}{ Inflation (t-1) } & & & -0.1101 & & & -0.1324 \\
\hline & & & 0.0728 & & & 0.0820 \\
\hline Number of observations & 2426 & 2270 & 2386 & 2174 & 2048 & 2152 \\
\hline Number of countries & 120 & 112 & 119 & 117 & 111 & 117 \\
\hline
\end{tabular}




\section{Appendix VII. Robustness-Credit Booms, Financial Reforms and Banking Supervision}

Dependent variable: Binary variable that takes the value of 1 when there is a credit boom

\begin{tabular}{|c|c|c|c|c|}
\hline & [1] & {$[2]$} & [3] & {$[4]$} \\
\hline \multirow[t]{2}{*}{ Gross other investments/GDP (t-1) } & 0.1765 & 0.2370 & 0.0278 & 0.1237 \\
\hline & 1.3866 & 1.3883 & 1.3945 & 1.3907 \\
\hline \multirow[t]{2}{*}{ Gross other investments/GDP (t-2) } & $3.0959 * *$ & $3.0777^{* *}$ & $3.0413 * *$ & $2.9091 * *$ \\
\hline & 1.4198 & 1.4205 & 1.4269 & 1.4281 \\
\hline \multirow[t]{2}{*}{ Private sector credit/GDP (t-1) } & $2.4439 * * *$ & $2.4361 * * *$ & $2.4163 * * *$ & $2.4020 * * *$ \\
\hline & 0.4433 & 0.4462 & 0.4407 & 0.4422 \\
\hline \multirow[t]{2}{*}{ GDP growth rate $(\mathrm{t}-1)$} & -1.0967 & -1.0226 & -1.1637 & -1.0906 \\
\hline & 1.3752 & 1.3777 & 1.3771 & 1.3801 \\
\hline \multirow[t]{2}{*}{ Growth rate of private sector credit-to-GDP (t-1) } & $2.2494 * * *$ & $2.2710 * * *$ & $2.2675^{* * *}$ & $2.2644^{* * *}$ \\
\hline & 0.3844 & 0.3856 & 0.3862 & 0.3859 \\
\hline \multirow[t]{2}{*}{ Growth rate of external demand $(\mathrm{t}-1)$} & $6.2869 *$ & $6.1853 *$ & $6.2061 *$ & $6.1025 *$ \\
\hline & 3.6104 & 3.6292 & 3.6065 & 3.6231 \\
\hline \multirow[t]{2}{*}{ Trade openness (t-1) } & $-1.1783 * * *$ & $-1.1079 * * *$ & $-1.2033 * * *$ & $-1.1266 * * *$ \\
\hline & 0.3247 & 0.3326 & 0.3232 & 0.3296 \\
\hline \multirow[t]{2}{*}{ Exchange rate flexibility (t-1) } & 0.0200 & 0.0196 & 0.0188 & 0.0181 \\
\hline & 0.0236 & 0.0236 & 0.0237 & 0.0237 \\
\hline \multirow[t]{2}{*}{ Exchange rate flexibility (t-2) } & -0.0119 & -0.0115 & -0.0119 & -0.0124 \\
\hline & 0.0224 & 0.0225 & 0.0224 & 0.0225 \\
\hline \multirow[t]{2}{*}{ Cylcical component of U.S. federal funds rate (t-3) } & $-0.0711^{* *}$ & $-0.0695 * *$ & $-0.0744 * *$ & $-0.0736 * *$ \\
\hline & 0.0320 & 0.0322 & 0.0320 & 0.0320 \\
\hline Financial reform index $1 /$ & 0.0505 & & & \\
\hline (one period change: $t-t-1$ ) & 0.0552 & & & \\
\hline Financial reform index & & 0.0299 & & \\
\hline (two period change: $t-t-2$ ) & & 0.0366 & & \\
\hline \multirow{2}{*}{$\begin{array}{l}\text { Banking supervision and regulations index } 2 \text { / } \\
\text { (one period change: } t-t-1 \text { ) }\end{array}$} & & & -0.1598 & \\
\hline & & & 0.2113 & \\
\hline \multirow{2}{*}{$\begin{array}{l}\text { Banking supervision and regulations index } \\
\text { (two period change: } t-t-2 \text { ) }\end{array}$} & & & & -0.1748 \\
\hline & & & & 0.1617 \\
\hline Number of observations & 1258 & 1257 & 1258 & 1257 \\
\hline Number of countries & 60 & 60 & 60 & 60 \\
\hline \multicolumn{5}{|c|}{ 1/ A modified financial reform index from Abiad et al. (2008). The index used in the regression includes the following dimensions: } \\
\hline \multicolumn{5}{|c|}{ (i) credit controls and excessively high reserve requirements, (ii) Interest rate controls, (iii) entry barriers, (iv) State ownership in the } \\
\hline \multicolumn{5}{|c|}{ banking sector, (v) capital account restrictions, and (vi) securities market policy. The modified index excludes banking supervision . } \\
\hline \multicolumn{5}{|c|}{ and prudential regulations. } \\
\hline \multicolumn{5}{|c|}{ 2/Index of prudential regualation and banking supervision (Abiad et al., 2008). } \\
\hline \multicolumn{5}{|c|}{ Credit boom epsiodes are identified using the Mendoza and Terrones methodology (2012). Panel Probits estimated with random-effects. } \\
\hline
\end{tabular}

